Article

\title{
Prediction of Holocene Mercury Accumulation Trends by Combining Palynological and Geochemical Records of Lake Sediments (Black Forest, Germany)
}

\author{
Martin Schütze ${ }^{1, * \mathbb{C}}$, Gegeensuvd Tserendorj ${ }^{2}$, Marta Pérez-Rodríguez ${ }^{1} \mathbb{C}$, Manfred Rösch ${ }^{2} \mathbb{C}$ \\ and Harald Biester ${ }^{1}$ \\ 1 Institut für Geoökologie, AG Umweltgeochemie, Technische Universität Braunschweig, Langer Kamp 19C, \\ 38106 Braunschweig, Germany; m.perez-rodriguez@tu-bs.de (M.P.-R.); h.biester@tu-bs.de (H.B.) \\ 2 Labor für Archäobotanik, Landesamt für Denkmalpflege im RP Stuttgart, Fischersteig 9, \\ 78343 Gaienhofen, Germany; gegeensuvd.tserendorj@rps.bwl.de (G.T.); manfred.roesch@rps.bwl.de (M.R.) \\ * Correspondence: martin.schuetze@tu-bs.de
}

Received: 17 August 2018; Accepted: 11 September 2018; Published: 21 September 2018

\begin{abstract}
Forest vegetation plays a key role in the cycling of mercury $(\mathrm{Hg})$ and organic matter $(\mathrm{OM})$ in terrestrial ecosystems. Litterfall has been indicated as the major transport vector of atmospheric $\mathrm{Hg}$ to forest soils, which is eventually transported and stored in the sediments of forest lakes. Hence, it is important to understand how changes in forest vegetation affect $\mathrm{Hg}$ in soil and its biogeochemical cycling in lake systems. We investigated the pollen records and the geochemical compositions of sediments from two lakes (Schurmsee and Glaswaldsee) in the Black Forest (Germany) to evaluate whether long-term shifts in forest vegetation induced by climate or land use influenced $\mathrm{Hg}$ accumulation in the lakes. We were particularly interested to determine whether coniferous forests were associated with a larger export of $\mathrm{Hg}$ to aquatic systems than deciduous forests. Principal components analysis followed by principal component regression enabled us to describe the evolution of the weight of the latent processes determining the accumulation of $\mathrm{Hg}$ over time. Our results emphasize that the in-lake uptake of $\mathrm{Hg}$ during warm climate periods, soil erosion after deforestation and emissions from mining and other human activities triggered changes in $\mathrm{Hg}$ accumulation during the Holocene stronger than the changes caused by forest vegetation alone.
\end{abstract}

Keywords: mercury accumulation; lake sediment; Holocene; landscape development

\section{Introduction}

Mercury is a pollutant of concern due to its toxicity and high bio-magnification potential in aquatic systems; because $\mathrm{Hg}$ is organophilic, $\mathrm{OM}$ is a key component to determine the retention and transport of $\mathrm{Hg}$ in the environment [1,2]. Widely observed increases in $\mathrm{Hg}$ concentrations and accumulation rates in lake sediments deposited during the past century are commonly accepted as records of increasing anthropogenic input of $\mathrm{Hg}$ to the atmosphere and atmospheric deposition of $\mathrm{Hg}$ to lake sediments [3-6]. Lake sediments accumulate material from the entire catchment and thus can be understood as a record of $\mathrm{OM}$ and many major and trace elements, including $\mathrm{Hg}[7,8]$. Because new material is deposited on top of older deposits, these sediments are also natural archives for temporal changes in trace element loadings [9-11]. Most studies of Hg in lake sediments have focused on correcting $\mathrm{Hg}$ accumulation in sediments for catchment effects to convert $\mathrm{Hg}$ accumulation rates into atmospheric deposition rates $[5,12,13]$. The effects of the evolution of landscapes on $\mathrm{Hg}$ transport and the accumulation of this element to and within aquatic systems have been considered to a much lesser extent. It is well established that the vegetation type influences the cycling of OM 
and trace element transport in several ways. First, the presence of vegetation stabilizes catchment soils and reduces the transport of particulate materials to surface waters [14]. Second, vegetation has an influence on the amount of litter that is produced, e.g., deciduous trees produce more litter than coniferous trees, which affects the trace element concentrations in the released dissolved organic matter (DOM) [15,16]. Third, vegetation and OM quality affect soil development, e.g., deciduous litter promotes the presence of invertebrates and soil mixing, which results in longer contact times between OM and soil mineral particles [17]. Fourth, differences in plant species compositions affect the interception area, which in turn affects the sequestration of atmospherically deposited trace elements [1,18]. Fifth, litter from different vegetation types decomposes at different rates, depending, e.g., on the litter chemical composition $[19,20]$. This affects the production of DOM and the amount of trace elements bound to each unit of OM so that more decomposed OM has higher Hg concentrations. Some studies have shown that $\mathrm{Hg}$ concentrations are higher in the litter of coniferous forests than deciduous forests [21,22]. In contrast, others studies have demonstrated that $\mathrm{Hg}$ concentrations in coniferous litter may be lower than those in deciduous litter $[1,23,24]$, which might be due to varying conditions of atmospheric $\mathrm{Hg}$ concentrations or exposure. Jiskra et al. [25] indicated, with $\mathrm{Hg}$ isotope analyse in boreal soils, that $90 \%$ of $\mathrm{Hg}$ in forest soil is deposited by litter. While the vegetation acts as a short-term sink for atmospheric $\mathrm{Hg}$, forest soils can be regarded as long-term sinks [26]. Drenner et al. [27] linked Hg levels in freshwater fish to the percentage of the landscape covered by coniferous forests. This highlights the significant effect of vegetation on the transfer of $\mathrm{Hg}$ to aquatic systems. Large natural variations in the $\mathrm{Hg}$ content in lake sediments have been observed, suggesting influences by site-specific vegetation-and forest fire history, soil type, morphology, hydrology, and climate variability [12,28-32].

One option to reduce the effect of site history, soil type, morphology and hydrology differences is to investigate the long-term effects of vegetation change and landscape development in a single system using long sediment records [33]. In this study, we analysed lake sediment records from two small headwater lakes, Schurmsee and Glaswaldsee in southwest Germany. The two lake sediment cores extend back to $\sim 9500$ years before present (yr BP) and reflect two major vegetation changes in the Holocene. During the time period from 9500 to $2500 \mathrm{yr}$ BP atmospheric $\mathrm{Hg}$ deposition in central Europe was relatively constant $[34,35]$. Therefore, the two lake systems can be used as natural archives to reconstruct how changes between diverse vegetation cover types have affected the accumulation of $\mathrm{Hg}$ in the sediment from a long-term perspective. Considering the results of a preliminary work in this region by Rydberg et al. [33], we expected a pronounced variation in the $\mathrm{Hg}$ concentration in the lake sediments after pollen inferred changes in vegetation, and a significant increase in human impacts on the sediment geochemical composition from the Bronze Age onwards.

The main objective of this research was to combine the pollen-derived vegetation history and the geochemical composition of sediment records from the two lakes to assess how vegetation shifts affect the accumulation of $\mathrm{Hg}$ in lakes. Using multivariate statistical methods, we attempted to determine the main factors that controlled $\mathrm{Hg}$ deposition in lake sediments over a long-time scale (from Mesolithic to Modern Age) and to quantify the relative effects of these factors on $\mathrm{Hg}$ accumulation. This provides an opportunity to determine whether the observed changes in $\mathrm{Hg}$ accumulation were primarily caused by shifts in vegetation or whether other catchment-specific factors overwrote the influence of vegetation.

\section{Materials and Methods}

\subsection{Site Description}

The two studied lakes, Schurmsee (795 m a.s.1., $\left.48^{\circ} 36^{\prime} 47^{\prime \prime} \mathrm{N}, 8^{\circ} 19^{\prime} 09^{\prime \prime} \mathrm{E}\right)$ and Glaswaldsee (839 m a.s.1., $48^{\circ} 25^{\prime} 33^{\prime \prime} \mathrm{N}, 8^{\circ} 15^{\prime} 41^{\prime \prime} \mathrm{E}$ ), are small headwater lakes situated $23 \mathrm{~km}$ apart in the northern Black Forest, southwest Germany (Figure 1). The anthropogenic pressure on the lakes is currently relatively low. There are no settlements in the catchments, and only small forest tracks surround the study sites. The lakes have similar maximum water depths of 11-13 m, surface areas of $1.5 \mathrm{ha}$ and 
2.9 ha and lake-to-catchment-area ratios of approximately 1:34 and 1:18, respectively. The catchment topography was formed in a cirque excavated by glaciers, so the cupped sections of both lakes are relatively steep. The shoreline of Schurmsee is lined with a floating mat of Sphagnum. Surrounding soils at both sites are dominated by acidified podzolic soils from Triassic sandstone rubble [36]. The climate is sub-oceanic, with decreasing temperatures and increasing precipitation as altitude increases. The annual average temperature, e.g., in Freudenstadt ( $732 \mathrm{~m}$ a.s.1., $\left.48^{\circ} 27^{\prime} 4^{\prime \prime} \mathrm{N}, 8^{\circ} 24^{\prime} 3^{\prime \prime} \mathrm{E}\right)$, is $7^{\circ} \mathrm{C}$, the mean annual precipitation is $1680 \mathrm{~mm}$, and in that area, there are approximately 108 frost days $\left(\mathrm{T}_{\min } \leq 0^{\circ} \mathrm{C}\right.$ ) per year [37]. Water budget measurements from 1985 to 1992 in the catchment at nearby Herrenwiesersee yielded a mean annual precipitation of $1931 \mathrm{~mm}$ [38]. The current lake water $\mathrm{pH}$ is $4.2-4.9$ in the water column at both lakes. Depending on the water depth, the dissolved organic carbon concentration ranges from $6-15 \mathrm{mg} \mathrm{L}^{-1}$ at Schurmsee and from $15-19 \mathrm{mg} \mathrm{L}^{-1}$ at Glaswaldsee. The dissolved inorganic carbon is $<0.5 \mathrm{mg} \mathrm{L}^{-1}$ and considered negligible. The present-day vegetation of the catchment area at both sites consists of managed coniferous forests dominated by Picea abies (Norway spruce). Pollen analysis of local sediment cores revealed that, similar to many other areas in Europe, several vegetation changes occurred at the study site during the Holocene $[39,40]$.

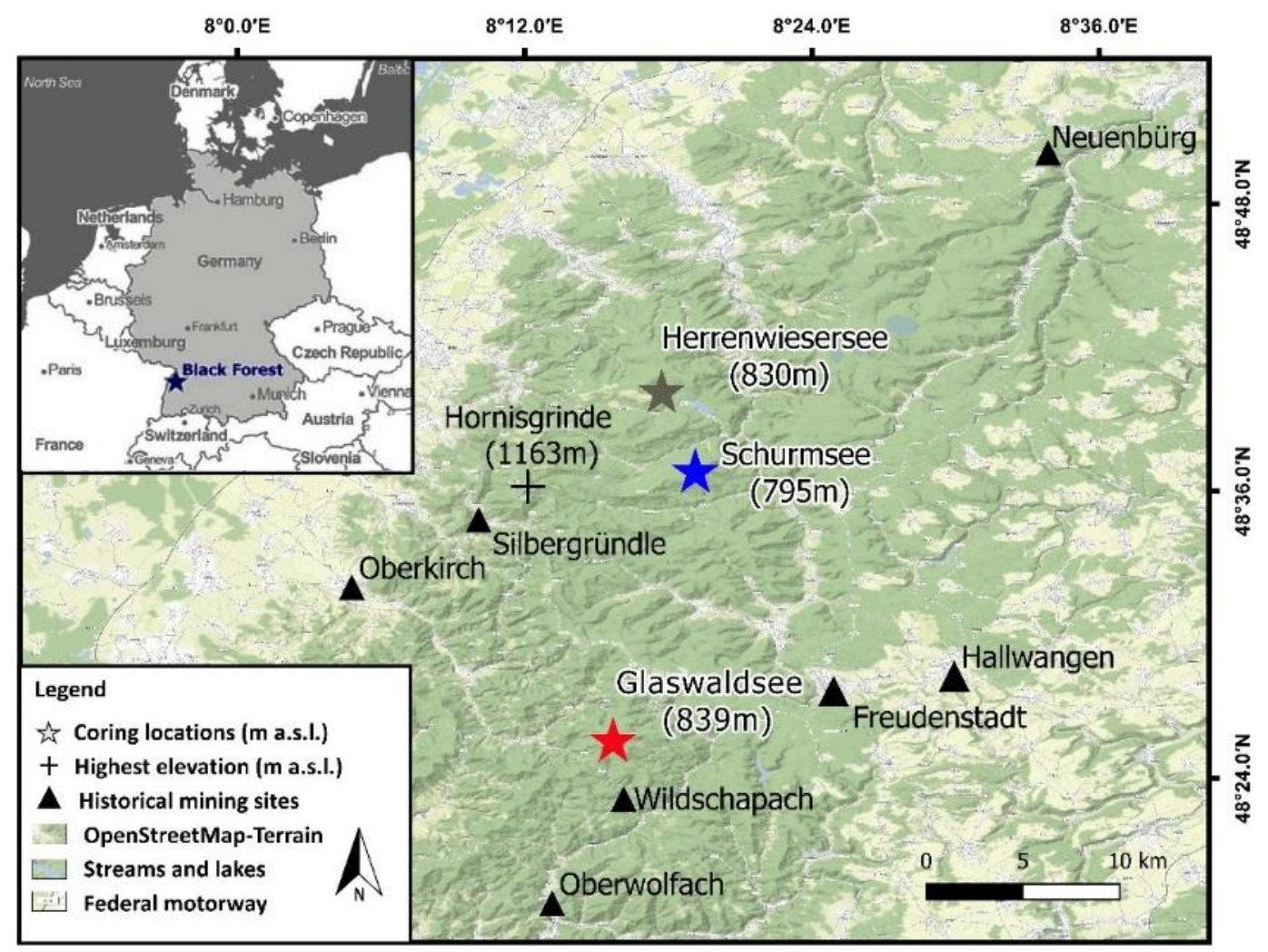

Figure 1. Map of the northern Black Forest showing the coring locations at Herrenwiesersee (grey star, Rydberg et al. [33]), Schurmsee (blue star), and Glaswaldsee (red star), as well as the topography, former mining sites and present-day land cover. Inset: localization of the study area in central Europe.

\subsubsection{Coring}

In 2006, two long cores were collected in the centre of the lakes at maximum water depth using a modified Livingstone-corer [40,41]. The long cores have a diameter of $5 \mathrm{~cm}$ and lengths of $526 \mathrm{~cm}$ at Schurmsee and $175 \mathrm{~cm}$ at Glaswaldsee. The cores were sub-sampled with a high resolution of $1 \mathrm{~cm}$ for pollen analysis and with a lower resolution of $4 \mathrm{~cm}$ and $2 \mathrm{~cm}$ for geochemical analysis at Schurmsee and Glaswaldsee, respectively. The palynological reconstruction of Glaswaldsee have been reported by Rösch [40], whereas the pollen records of Schurmsee are unpublished data. For statistical reasons, the resolution of the pollen data used in this paper was reduced to the resolution of geochemical data 
for both cores. Data for the upper $28 \mathrm{~cm}$ were not available at Schurmsee. Therefore, a short sediment core was taken in 2017 using a UWITEC gravity corer. At Schurmsee, pollen data begin at a depth of $28 \mathrm{~cm}$. According to the pollen spectra preserved by mosses from the shore of Herrenwiesersee [42], the pollen values for the statistical approaches were considered constant over the upper $28 \mathrm{~cm}$ at Schurmsee. A detailed description of the sample preparation and palynological analysis methods is given in Rösch and Lechterbeck [43]. The samples for the geochemical investigations were stored at $-20{ }^{\circ} \mathrm{C}$ in the dark until analysis. All core samples were oven dried at $<40{ }^{\circ} \mathrm{C}$ and ground using a Retsch agate ball mill.

\subsubsection{Chronology}

The sediment chronology was established by a ${ }^{14} \mathrm{C}$-analysis, using 17 bulk sediment samples for Schurmsee and 16 bulk sediment samples for Glaswaldsee (Supplementary Materials, Tables SM-1 and SM-2). For both sediment cores shown in this research, calibrated ages were obtained using the InterCal13.14C curve [44], and age-depth modelling was conducted with CLAM 2.2 using the smooth spline function [45]. One date from the Glaswaldsee core at $55 \mathrm{~cm}$ depth was excluded from the age-depth model because inclusion of the point resulted in an unrealistic sediment accumulation rate in this section of the profile. Samples below $400 \mathrm{~cm}$ at Schurmsee were not included in this study due to missing ${ }^{14} \mathrm{C}$ data and indicated multiple impacts of post-glacial erosion. Based on the age-depth model, the deepest sediment layers at both lakes were dated to 9500 calibrated (CAL) yr BP. The average error for the age-depth estimates was $110 \mathrm{yr}$ at Schurmsee and $183 \mathrm{yr}$ at Glaswaldsee (Figures SM-1 and SM-2).

\subsection{Chemical Analysis}

\subsubsection{Carbon, Nitrogen and Sulphur}

Total carbon $(\mathrm{C})$, nitrogen $(\mathrm{N})$ and sulphur $(\mathrm{S})$ were analysed using a EuroEA 3000 elemental analyser (Hekatech $\mathrm{GmbH}$, Germany). The ratios of C:N are an indicator of organic matter sources [46]. The quality of the analysis was ensured by the inclusion of five certified reference materials (CRM). Two of the CRMs were pure chemical substances, i.e., sulphanilamide (C $=41.75 \pm 0.17 \%$; $\mathrm{N}=16.26 \pm 0.22 \% ; \mathrm{S}=18.64 \pm 0.18 \%$ ) and BBOT (2.5-Bis(5-tert-butyl-benzoxazol-2-yl)thiophene; $\mathrm{C}=72.52 \% ; \mathrm{N}=6.51 \% ; \mathrm{S}=7.44 \%$ ), while three represented natural samples, i.e., NIST 1515 apple leaves $(\mathrm{N}=2.25 \pm 0.19 \%)$, Canmet LKSD-4 lake sediment $(\mathrm{C}=17.7 \pm 0.8 \%$; $\mathrm{S}=0.99 \pm 0.09 \%)$ and MOC soil standard $C=3.19 \pm 0.07 \%)$. Average results for the SRMs were sulphanilamide $(\mathrm{n}=60)$ $\mathrm{C}=41.86 \pm 0.42 \%, \mathrm{~N}=16.47 \pm 2.54 \%$ and $\mathrm{S}=18.87 \pm 2.71 \%$; BBOT $(\mathrm{n}=14) \mathrm{C}=72.42 \pm 0.52 \%$, $\mathrm{N}=6.49 \pm 3.08 \%$ and $\mathrm{S}=7.17 \pm 4.69 \%$; NIST $1515(\mathrm{n}=9) \mathrm{N}=2.34 \pm 2.56 \%$; LKSD-4 $(\mathrm{n}=4)$ $\mathrm{C}=18.88 \pm 0.62 \%$ and $\mathrm{S}=0.98 \pm 1.53 \%$ and MOC $(\mathrm{n}=14) \mathrm{C}=3.24 \pm 2.52 \%$. Triplicate analyses $(\mathrm{n}=14)$ gave relative standard deviations (RSD) of $1.57 \%, 2.26 \%$ and $2.71 \%$ for $\mathrm{C}, \mathrm{N}$, and $\mathrm{S}$, respectively. According to pre-measurements using the "Karbonat-Bombe" method [47], the carbonate concentrations in the sediment were negligible. Hence, the measured carbon concentrations can be considered equivalent to the total organic carbon (TOC).

\subsubsection{Major and Trace Elements}

Total concentrations of several major and trace elements, i.e., aluminium (Al) titanium (Ti), iron $(\mathrm{Fe})$, manganese $(\mathrm{Mn})$, copper $(\mathrm{Cu})$, zinc $(\mathrm{Zn})$, zirconium $(\mathrm{Zr})$, and lead $(\mathrm{Pb})$, were analysed by means of energy-dispersive X-ray fluorescence (ED-XRF). Repeated analysis of two CRM lake sediments (Canmet LKSD-4, IAEA-SL-1) and sample triplicates gave RSD less than 10\% for the CRMs, Ti, Zn, Zr, $\mathrm{Fe}$ and $\mathrm{Pb}, 7-19 \%$ for $\mathrm{Al}, 4-18 \%$ for $\mathrm{Mn}$, and $3-23 \%$ for $\mathrm{Cu}$. A detailed explanation about the calibration method, accuracy and precision is given in Cheburkin and Shotyk [48]. 


\subsubsection{Mercury}

The Hg content in the lake sediments was analysed by thermal decomposition followed by pre-concentration of $\mathrm{Hg}$ on a gold trap and cold vapour atomic absorption spectrophotometry (CV-AAS) $\mathrm{Hg}$ detection using a Milestone DMA-80 direct mercury analyzer [49]. Mercury concentrations are reported per dry weight. To ensure the analytical quality, two CRM lake sediments, i.e., Canmet LKSD-4 (190 $\left.\pm 17 \mathrm{ng} \mathrm{g}^{-1}\right)$ and IAEA-SL-1 $\left(130 \pm 50 \mathrm{ng} \mathrm{g}^{-1}\right)$, were included alongside the analysed samples. The average results for the CRMs were as follows: LKSD-4 $(\mathrm{n}=25), \mathrm{Hg}=191 \pm 7 \mathrm{ng} \mathrm{g}^{-1}$ and IAEA-SL-1 $(\mathrm{n}=6), \mathrm{Hg}=125 \pm 4 \mathrm{ng} \mathrm{g}^{-1}$. Randomly selected samples were analysed as triplicates $(\mathrm{n}=18)$. The RSD between sample replicates was $1.2 \%$ (range $0.1-6.1 \%$ ), which ensures that the samples were homogeneous.

\subsection{Sedimentation Rates}

Sedimentation rates are naturally not steady over a long-term period such as $9500 \mathrm{yr}$ BP (Figures SM-1 and SM-2). The mean sedimentation rate at Schurmsee was more than two-fold higher than that at Glaswaldsee. Nevertheless, the two sediment cores are suitable for comparison because their pollen histories show similar trends over time, which is a mandatory requirement for contrasting the geochemical evolution of both lake sediments in this study. The dry mass sediment accumulation rate $\left(\mathrm{g} \mathrm{cm}^{-2} \mathrm{yr}^{-1}\right)$ was calculated as the product of the mean bulk density of a given sediment layer $\left(\mathrm{g} \mathrm{cm}^{-3}\right)$ and the interval represented by the given section $(\mathrm{cm})$, divided by the time duration $(\mathrm{yr})$, estimated by the age-depth model. The $\mathrm{Hg}$ accumulation rate (i.e., observed) at each sediment layer $\left(\mu \mathrm{g} \mathrm{m}^{-2} \mathrm{yr}^{-1}\right.$ ) was calculated as the product of the $\mathrm{Hg}$ concentration $\left(\mathrm{ng} \mathrm{g}^{-1}\right)$ and dry mass sediment accumulation rate $\left(\mathrm{g} \mathrm{cm}^{-2} \mathrm{yr}^{-1}\right)$.

\subsection{Statistical Treatment}

Principal component analysis (PCA) was performed by combining pollen records and geochemical data to identify the main changes in the geochemical composition and relate these changes to underlying environmental processes. The advantage of this approach is that the sediment core is viewed as one unit for which co-variations between different sediment variables are used to describe main patterns by a few significant components (CPs). Each component combines variables with similar downcore trends that are likely controlled by the same underlying processes, e.g., elements that are affected by erosion events in the catchment. The PCA was performed separately for both cores using the following 18 variables: $\mathrm{Al}, \mathrm{Ti}, \mathrm{Fe}, \mathrm{Mn}, \mathrm{Cu}, \mathrm{Zn}, \mathrm{Zr}, \mathrm{Pb} \mathrm{C}, \mathrm{N}, \mathrm{C}: \mathrm{N}$ ratio, and hazel, oak, beech, fir, spruce, ribwort, and rye pollen. Moreover, a charcoal record that was only available from Glaswaldsee was included in the PCA of the Glaswaldsee study site. To avoid Hg influencing the principal components, $\mathrm{Hg}$ concentration was not used as a variable in the PCA. Prior to the analysis, all values were standardized (Z-scores) to avoid scaling effects and to obtain average centred distributions [50]. A varimax rotation was applied to maximize the loadings of the variables. Components with eigenvalues $<1$ were not considered and were sorted out.

In this study, we aimed to predict $\mathrm{Hg}$ accumulation based on environmental variables, including human activities, and to identify the primary effects influencing the $\mathrm{Hg}$ accumulation rates, without the influence of the bulk density, which may result in inaccurate observed $\mathrm{Hg}$ accumulation rate values. Based on the results of the PCA, a stepwise regression analysis (PCR) was performed using the $\mathrm{Hg}$ accumulation rate as the dependent variable and the scores of the extracted components as the predictors. The main advantage of using component scores rather than the original geochemical data in the regression analysis is that the rotated components represent new synthetic orthogonal variables, and the effects of these components within the regression analysis are additive. The record of the regression weights of the components with depth/time was used to evaluate the chronological variations of the controls on the $\mathrm{Hg}$ record [51]. All statistical calculations were performed within the statistic environment of R-version 3.3.3 [52]. 


\section{Results}

\subsection{Vegetation Changes and Land Use Practices}

The pollen records from Schurmsee and Glaswaldsee indicate that, after the post-glacial forest establishment, Corylus avellana (hazel) became the most dominant woody species until 8500 yr BP (Figure 2); thereafter, hazel was replaced by Quercus robur (oak). A second major change occurred between 5700-5300 yr BP when Abies alba (fir) and Fagus sylvatica (beech) took over as the most dominant tree species. Considering the altitude of the lakes, this mixed forest was likely dominated by Abies alba, but Fagus sylvatica was also present in the catchment. Among the herbs and grasses, there were indicators for several types of cultivated landscapes. Clear traces of human impacts due to grazing were observed between $3100 \mathrm{yr}$ BP and $2500 \mathrm{yr}$ BP by Plantago lanceolata (ribwort). The pollen analysis of the local sediment cores showed that, similar to many other areas in Europe, several vegetation dynamics occurred during the Holocene. Human activity (i.e., land use near both lakes) was clearly indicated by Secale cereale (rye) after $1200 \mathrm{yr}$ BP. The pollen findings of Picea abies (spruce) were less than 5\% until the Late Middle Ages. Due to the emergence of local forestry, spruce increased to $\sim 20 \%$ during the 19th century [53] and currently represents the dominant tree species in the northern Black Forest. Based on the vegetation dynamics and land use practices, the sediment records were divided into five time periods (Figure 2, section I to section V), e.g., for Schurmsee, these periods were prior to 8400, 8400-5100, 5100-2600, 2600-1600 and after 1600 yr BP. To improve the chronological comparability between the locations, a linear age-depth distribution was applied.

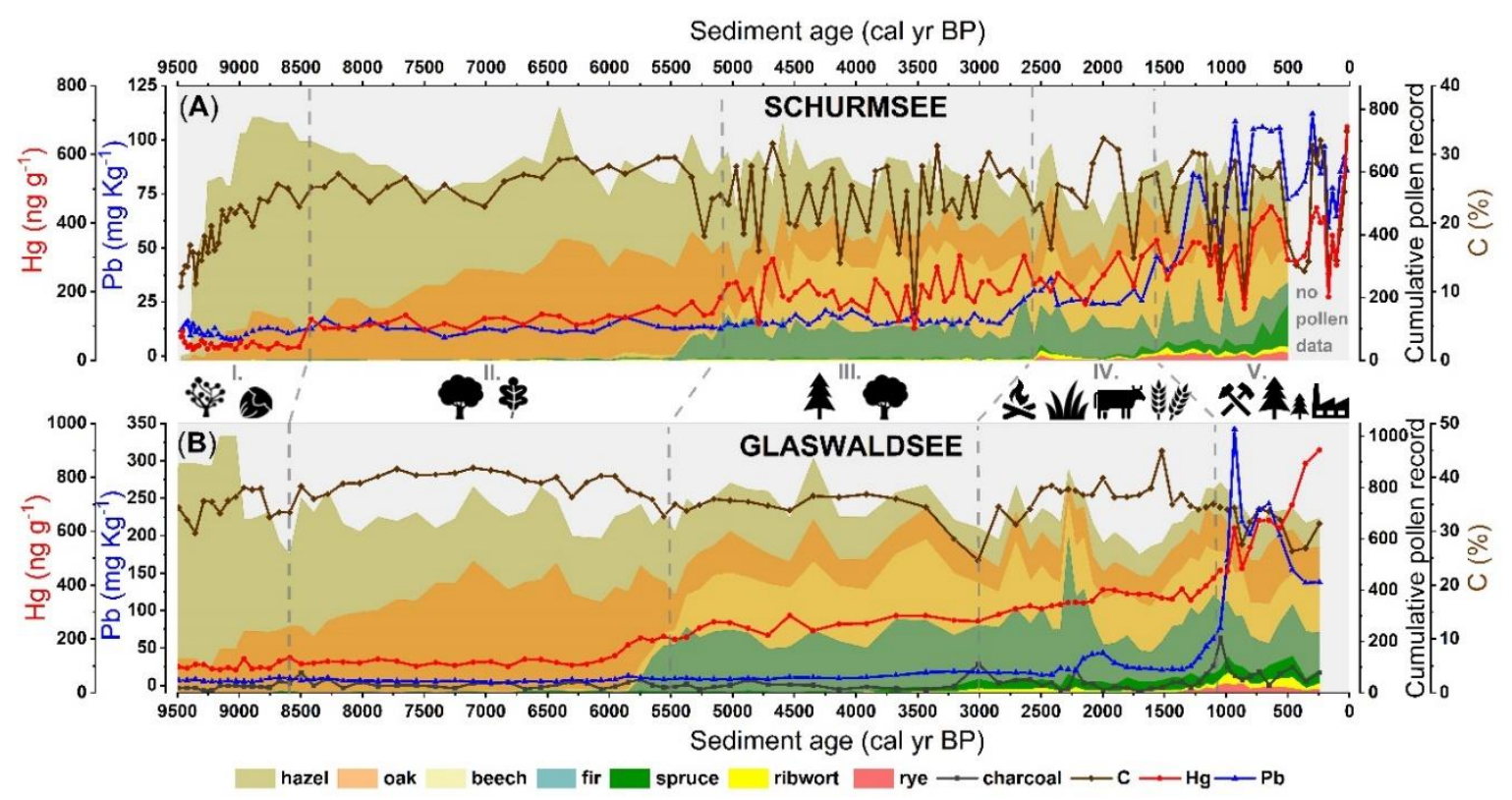

Figure 2. Cumulative historical pollen records for hazel, oak, beech, fir, spruce, ribwort and rye (coloured stacked area) and concentrations of $\mathrm{C}$ (brown line), $\mathrm{Hg}$ (red line), and $\mathrm{Pb}$ (blue line) for Schurmsee (A) and Glaswaldsee (B) by linear age-depth distribution. In addition, a charcoal record (grey line) is shown for Glaswaldsee, and indicators (black symbols) of the vegetation cover types and human-caused impacts are shown for both catchments.

\subsection{Holocene Records of Mercury and Lead Concentrations}

Mercury concentrations varied from the oldest (section I.) to the earliest core layers (section V.) from 72 to $680 \mathrm{ng} \mathrm{g}^{-1}$ at Schurmsee and from 95 to $901 \mathrm{ng} \mathrm{g}^{-1}$ at Glaswaldsee. Schurmsee showed a sharp increase in $\mathrm{Hg}$ concentrations from 43 to $116 \mathrm{ng} \mathrm{g}^{-1}$ (Figure 2A) when oak replaced hazel as the dominat tree species at $\sim 8500 \mathrm{yr}$ BP, while the $\mathrm{Hg}$ concentrations at Glaswaldsee increased from 117 to $130 \mathrm{ng} \mathrm{g}^{-1}$ during this first forest change. After the formation of a mixed forest with fir and 
beech at $\sim 5100$ yr BP at Schurmsee and $\sim 5500$ yr BP at Glaswaldsee, the Hg concentration increased to $182 \mathrm{ng} \mathrm{g}^{-1}$ and $209 \mathrm{ng} \mathrm{g}^{-1}$, respectively. Since a mixed forest was established in the catchment of Schurmsee, the $\mathrm{Hg}$ record was more unstable, i.e., it was influenced by a number of erosion events, as indicated by rapid declines in the carbon concentrations (Figure 2), and simultaneous increases in the titanium concentrations (Figure 3). Between 3000 and $2600 \mathrm{yr} \mathrm{BP}$, the Hg concentrations in both sediment cores started to increase simultaneously. During the same period, the first signals of grazing activities shown by ribworth pollen were observed. The $\mathrm{Hg}$ concentrations in these sediment layers (section IV.) reached up to $350 \mathrm{ng} \mathrm{g}^{-1}$ at Schumrsee and $344 \mathrm{ng} \mathrm{g}^{-1}$ at Glaswaldsee. However, the highest $\mathrm{Hg}$ concentrations in both cores were observed in the surface layers (section V.), which was temporally related to the Industrial Age. $\mathrm{Hg}$ concentrations reached up to $680 \mathrm{ng} \mathrm{g}^{-1}$ and $901 \mathrm{ng} \mathrm{g}^{-1}$, respectively.

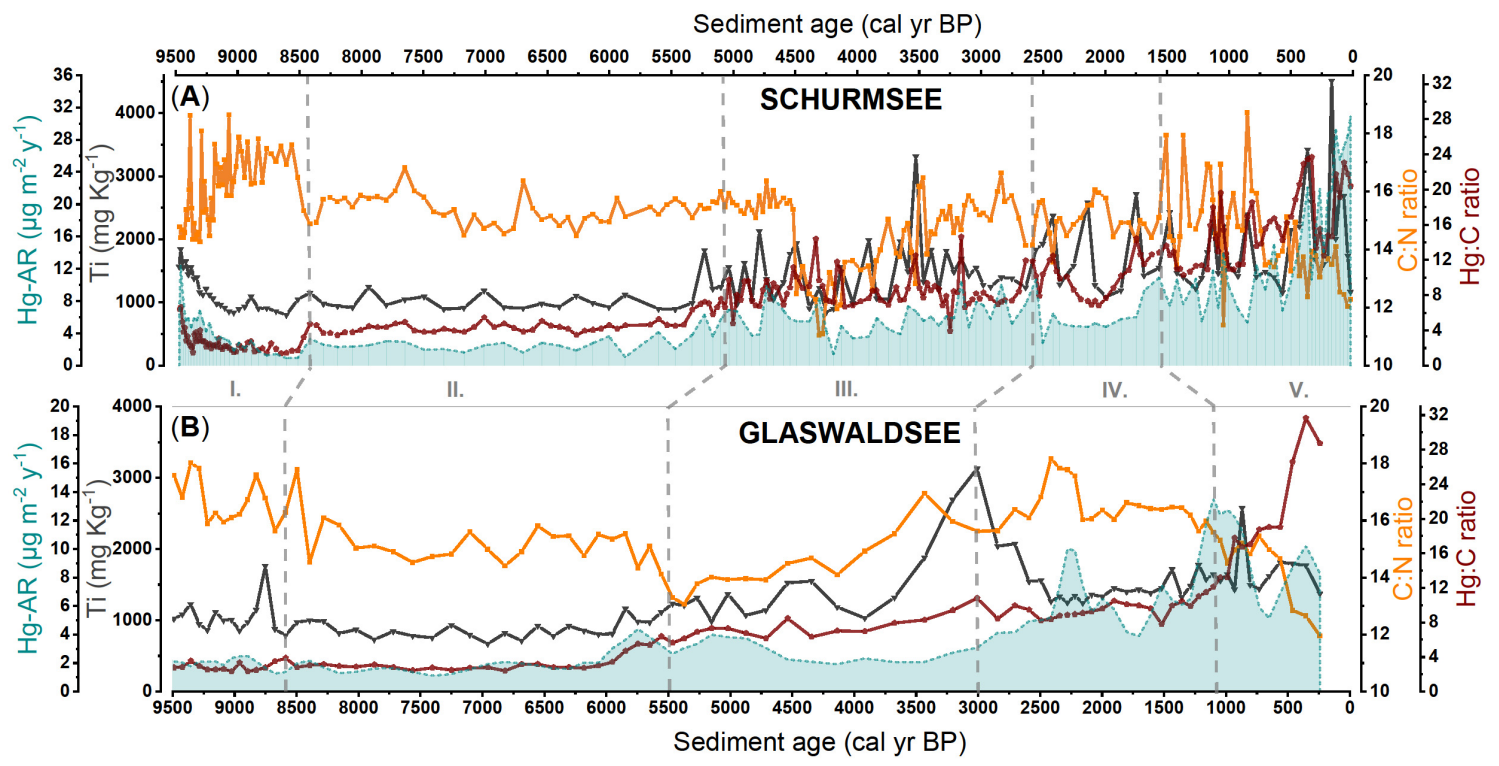

Figure 3. Titanium concentrations (dark-grey line) as indicators of mineral matter erosion, carbon/nitrogen ratios (orange line) as indicators of organic matter sources and observed mercury accumulation rates (grey-blue area), mercury/carbon ratios (dark red line) as an indicator of the interaction of atmospheric $\mathrm{Hg}$ fluxes and organic matter sources for Schurmsee (A) and Glaswaldsee (B) by linear age-depth distribution.

In comparison to the $\mathrm{Hg}$ records, the $\mathrm{Pb}$ records were relatively constant over core section $\mathrm{I}$. to section III. (Figure 2), which showed a mean Pb concentration of $13.7 \mu \mathrm{g} \mathrm{g}^{-1}$ at Schurmsee and $8.3 \mu \mathrm{g} \mathrm{g}^{-1}$ at Glaswaldsee. The first significant increases in the $\mathrm{Pb}$ concentrations appeared in section IV. and were concurrent with other indicators (e.g., ribwort) of increasing human settlement activity. The strongest $\mathrm{Pb}$ signals during the High Medieval period peaked at $\sim 930 \mathrm{yr} \mathrm{BP}$ in section $\mathrm{V}$. and showed concentrations of $108 \mu \mathrm{g} \mathrm{g}^{-1}$ and $342 \mu \mathrm{g} \mathrm{g}^{-1}$, respectively. Corresponding to the high phase of local mining during the Medieval period, the $\mathrm{Pb}$ concentrations decline significantly in the upper sediment layers at $\sim 500 \mathrm{yr}$ BP of both lakes.

\subsection{Variation in Sediment Geochemistry Revealed from Principal Component Analysis}

The PCA resulted in six significant (i.e., eigenvalues > 1) components explaining $87 \%$ of the total variance in the palynological and geochemical data of both cores (Table 1). The first component (CP1), explaining $20 \%$ of the total variance at Schurmsee and $22 \%$ of the total variance at Glaswaldsee, was characterized by high loadings of $\mathrm{C}$ and $\mathrm{N}$, high contrary loadings for the soil erosion indicators $\mathrm{Zr}$, $\mathrm{Al}$ and $\mathrm{Ti}$, and moderate positive loadings for Mn at Glaswaldsee. The observed human impact was explained by CP2 (25\% and $19 \%$ of the total variance) and was indicated by high positive loadings 
of rye, ribwort, $\mathrm{Pb}$, and spruce. Spruce pollen showed a loading of 0.90 at Schurmsee, which was higher than the loading of 0.67 at Glaswaldsee. The charcoal record at Glaswaldsee resulted in a positive loading of 0.67 and indicated the anthropogenic influence within this component. The third component (CP3), which explained $18 \%$ of the total variance for both cores, was characterized by positive loadings for beech and fir, whereas hazel showed negative loadings. The fourth component (CP4), explaining 9\% and $6 \%$ of the total variance at Schurmsee and Glaswaldsee, respectively, was characterized by high loadings for oak and negative loadings for Fe at Schurmsee. The fifth component (CP5), which explained $8 \%$ of the total variance at both cores, showed high loadings for the C:N ratio and a moderate inverse loading for $\mathrm{Zn}$ at Schurmsee. The sixth component (CP6) explained 7\% and $14 \%$ of the total variance by high positive loadings of $\mathrm{Cu}$ at Schurmsee and high positive loadings of $\mathrm{Cu}, \mathrm{Zn}$, and Fe at Glaswaldsee.

Table 1. Factor loadings of six component (CPs) extracted by PCA using the pollen and geochemical element composition of the two Black Forest sediment cores: eigv.-eigenvalues, var.-percentage of proportional variance explained by each component. For reasons of comparability, no strict sorting according to loadings and eigenvalues was applied.

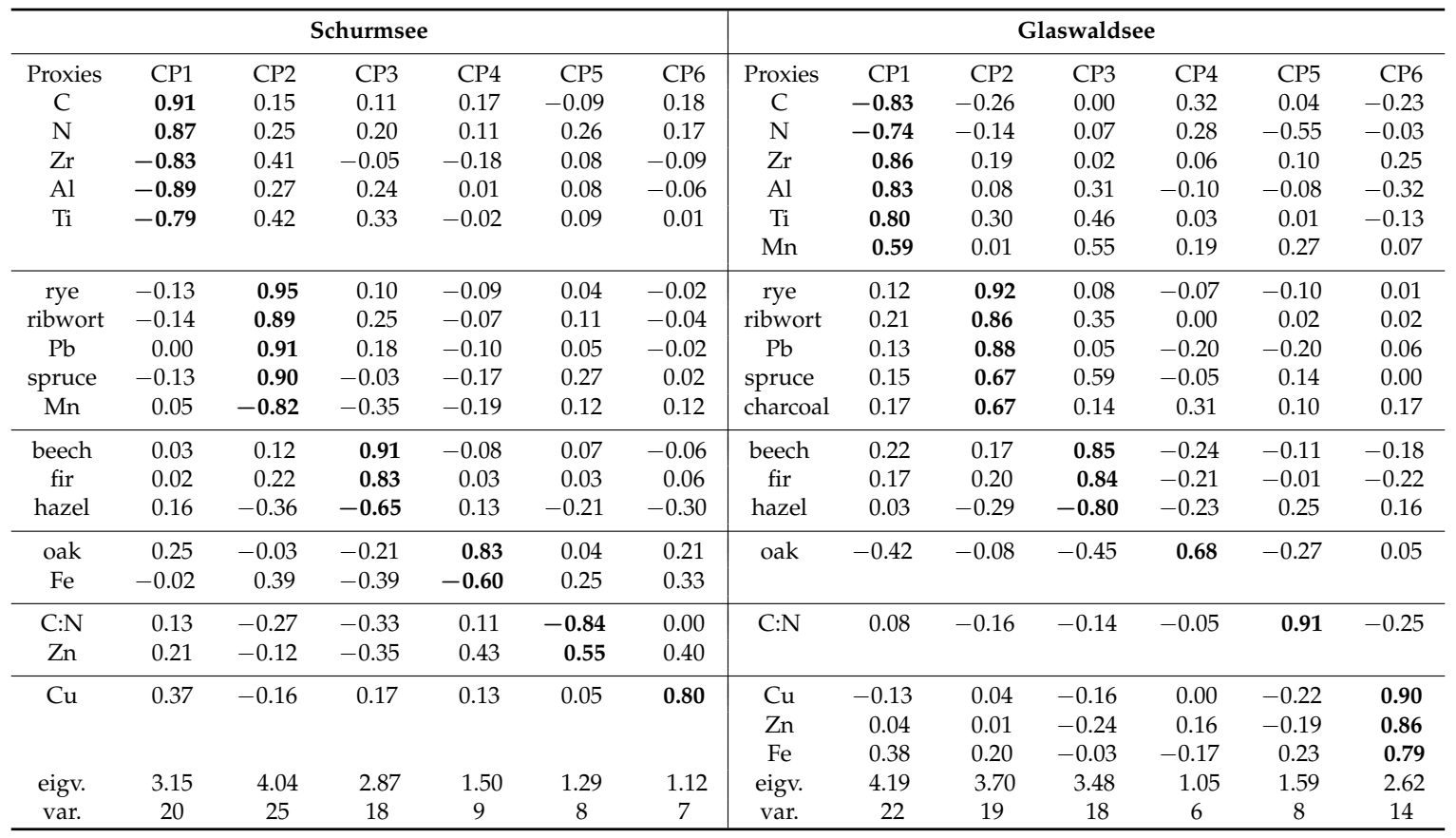

\subsection{Prediction of Factors Controlling Mercury Accumulation Using Stepwise Regression Analysis}

Here, the aim was to predict $\mathrm{Hg}$ accumulation rates based on sediment variables, including indicators of human activities, to identify the primary effects causing $\mathrm{Hg}$ accumulation. In addition, we were interested in whether coniferous forests led to a larger export of $\mathrm{Hg}$ to aquatic systems than deciduous forests. Table 2 presents the results of four (i.e., model 1a, 1b, 2a, and $2 b$ ) stepwise regression analyses (PCRs), which were performed using the $\mathrm{Hg}$ accumulation rate as the dependent variable and the scores of the extracted components as predictor variables. Regression model 1a implies that the score values from all six components were significant enough and were therefore used to explain the $\mathrm{Hg}$ accumulation at Schurmsee. Model 2a for the Glaswaldsee core shows that only three of the six components needed to be retained for the PCR to predict $\mathrm{Hg}$ accumulation. The regression models using the PCA variables suggest that $\mathrm{Hg}$ accumulation was predicted with a high accuracy at both Schurmsee $(0.88$, error \pm 0.49$)$ and Glaswaldsee $(0.82$, error \pm 0.59$)$. To assess the relevance of coniferous tree species on $\mathrm{Hg}$ accumulation, we excluded fir and spruce in a second step of the models. After excluding the conifers, shown here by the regression models $1 \mathrm{~b}$ and $2 \mathrm{~b}$, the $\mathrm{Hg}$ accumulation predictions showed slightly lower, but still high correlation coefficients for Schurmsee 
$(0.87$, error \pm 0.50$)$ and Glaswaldsee ( 0.80 , error \pm 0.62$)$. Because the analyses were performed with standardized variables, the regression coefficients were a measure of the weight of each factor on the variation of $\mathrm{Hg}$ accumulation over the last 9500 years in both lakes. In the models 1a and 2a, the factors weight decreases in the order of $\mathrm{CP} 2>\mathrm{CP} 5>\mathrm{CP} 4>\mathrm{CP} 1>\mathrm{CP} 3>\mathrm{CP} 6$ at Schurmsee and $\mathrm{CP} 2>\mathrm{CP} 3>\mathrm{CP} 5$ at Glaswaldsee. The components $\mathrm{CP} 2, \mathrm{CP} 3$, and CP5 showed a positive relationship with $\mathrm{Hg}$ accumulation, while $\mathrm{CP} 1$ and $\mathrm{CP} 4$ implied a negative effect on $\mathrm{Hg}$ accumulation. In addition, CP6 signified a moderate positive effect on $\mathrm{Hg}$ accumulation at Schurmsee.

Table 2. Stepwise regression analysis of CPs on $\mathrm{Hg}$ accumulation in the two sediment cores: components involved in the variations of $\mathrm{Hg}$ accumulation, regression coefficients of the significant CPs explaining $\mathrm{Hg}$ accumulation, $\mathrm{t}$-values (with positive relationship to $\mathrm{Hg}$ accumulation in bold), $p$-values, correlation coefficients $(\mathrm{R})$ in bold and errors for the four regression models; models $1 \mathrm{a}$ and $2 \mathrm{a}$ included all variables; models $1 \mathrm{~b}$ and $2 \mathrm{~b}$ excluded pollen data of coniferous tree species.

\begin{tabular}{|c|c|c|c|c|c|c|c|c|}
\hline & CP1 & $\mathrm{CP2}$ & CP3 & $\mathrm{CP} 4$ & CP5 & CP6 & $\mathbf{R}$ & Error \\
\hline \multicolumn{9}{|c|}{ model 1a SCHURMSEE } \\
\hline reg. coef. & -0.20 & 0.73 & 0.11 & -0.26 & 0.33 & 0.08 & 0.88 & 0.49 \\
\hline $\mathrm{t}$-value & -4.55 & 16.83 & 2.47 & -6.02 & 7.50 & 1.90 & & \\
\hline$p$-value & $<0.001$ & $<0.001$ & $<0.05$ & $<0.001$ & $<0.001$ & $<0.1$ & & \\
\hline \multicolumn{9}{|c|}{ model 1b SCHURMSEE } \\
\hline reg. coef. & -0.21 & 0.67 & 0.36 & -0.07 & 0.37 & - & 0.87 & 0.50 \\
\hline t-value & -4.59 & 14.90 & 8.16 & -1.62 & 8.25 & - & & \\
\hline$p$-value & $<0.001$ & $<0.001$ & $<0.001$ & $<0.1$ & $<0.001$ & - & & \\
\hline \multicolumn{9}{|c|}{ model 2a GLASWALDSEE } \\
\hline reg. coef. & - & 0.68 & 0.44 & - & 0.11 & - & 0.82 & 0.59 \\
\hline t-value & - & 10.81 & 6.92 & - & 1.74 & - & & \\
\hline$p$-value & - & $<0.001$ & $<0.001$ & - & $<0.1$ & - & & \\
\hline \multicolumn{9}{|c|}{ model 2b GLASWALDSEE } \\
\hline reg. coef. & - & 0.70 & 0.09 & -0.17 & - & - & 0.80 & 0.62 \\
\hline t-value & - & 10.50 & 5.06 & -2.55 & - & - & & \\
\hline$p$-value & - & $<0.001$ & $<0.001$ & $<0.05$ & - & - & & \\
\hline
\end{tabular}

\section{Discussion}

\subsection{Evolution of Mercury Concentration and Accumulation}

The sedimentary history of both lakes reflects strong environmental changes in the lake catchments over the past 9500 years. The $\mathrm{Hg}$ concentrations showed similar trends during the Holocene and increased from the oldest layers to the surface layers at Schurmsee $\left(72-680 \mathrm{ng} \mathrm{g}^{-1}\right)$ and Glaswaldsee (95-901 $\mathrm{ng} \mathrm{g}^{-1}$ ) by factors of 9.4 and 9.5, respectively. Large ranges of $\mathrm{Hg}$ concentrations within lake sediment cores have been reported, e.g., from lakes in Sweden $\left(\sim 100-900 \mathrm{ng} \mathrm{g}^{-1}\right)$ [54], the United Kingdom ( 20-1700 $\left.\mathrm{ng} \mathrm{g}^{-1}\right)$ [55], Switzerland $\left(\sim 20-700 \mathrm{ng} \mathrm{g}^{-1}\right)$ [35] and the United States $\left(\sim 40-380 \mathrm{ng} \mathrm{g}^{-1}\right)$ [32]. Corella et al. [56] found in a recent multi-lake study in the southern central Pyrenees increasing trends in $\mathrm{Hg}, \mathrm{Pb}$ and $\mathrm{Zn}$ over the past 1400 years, underlined by $\mathrm{Hg}$ enrichment factors up to 3.8, suggesting a mixed signal between local and global sources of trace metal pollution during this period. Moreover, the ranges of $\mathrm{Hg}$ concentrations observed in the two cores are similar to those found in Herrenwiesersee [33]. In the earliest layer at Herrenwiesersee (1566 yr BP), the reported $\mathrm{Hg}$ concentration was $316 \mathrm{ng} \mathrm{g}^{-1}$. This $\mathrm{Hg}$ concentration is slightly lower than the $\mathrm{Hg}$ concentrations found in comparable sediment layers in our study, showing $350 \mathrm{ng} \mathrm{g}^{-1}$ (1564 yr BP) at Schurmsee and $366 \mathrm{ng} \mathrm{g}^{-1}$ (1606 yr BP) at Glaswaldsee.

Long-term records encompassing $\mathrm{Hg}$ deposition over several thousands of years suggest a natural variability in the background values comparable to the recent anthropogenic forcing of the atmospheric $\mathrm{Hg}$ cycle $[28,32,57,58]$. Potential factors controlling pre-industrial $\mathrm{Hg}$ variations in lake sediments are natural changes in atmospheric fluxes. Long-term changes of $\mathrm{Hg}$ concentrations in polar ice, e.g., have 
been attributed to varying marine emissions coupled to oceanic productivity changes [59], whereas Guevara et al. [12] found a direct relationship between changing lake sediment $\mathrm{Hg}$ concentrations and volcanic eruptions in their study area. However, clear signals of Holocene volcanic eruptions could not be indicated in the two studied lake sediments. Besides the atmosphere, lake catchments are main $\mathrm{Hg}$ sources due to erosion of mineral particles or OM [60]. The amount of $\mathrm{Hg}$ transported from a catchment into adjacent aquatic systems is regulated by fluxes of terrestrial OM [61-64]. Hence, the Hg accumulation rates in lake sediments will be highly dependent on the export of $\mathrm{Hg}$ from catchment soils. In addition, the concentration will also be affected by, e.g., the influx of mineral matter relative to OM [65], the degradation state of OM [21], and the infilling of sediment with time that might affect sediment focusing [66].

In the two studied lakes, the terrestrial part of the catchment is considerably larger than the lake areas, but the ratio of lake surface area to catchment area is much higher at Schurmsee than at Glaswaldsee, which may have an import effect on the amount of OM transported to the lake sediments and their drivers (i.e., climate, vegetation). At Schurmsee, the recent $\mathrm{Hg}$ accumulation rate in the upper lake sediment layer was $31 \mu \mathrm{g} \mathrm{m}^{-2} \mathrm{yr}^{-1}$ (Figure 3), which is significantly higher than the present-day measurements of regional wet deposition, e.g., $21 \mu \mathrm{g} \mathrm{m}^{-2} \mathrm{yr}^{-1}$ at the northern Black Forest [67], indicating that a significant portion of the Hg input to the lake sediment was derived from the catchment runoff. However, the observed $\mathrm{Hg}$ accumulation in the sediment at Glaswaldsee peaked at $15 \mu \mathrm{g} \mathrm{m}^{-2} \mathrm{yr}^{-1}$ during the High Medieval mining period and showed a value of $8 \mu \mathrm{g} \mathrm{m}^{-2} \mathrm{yr}^{-1}$ in the upper lake sediment layer.

According to Hermanns and Biester [58], the precipitation-induced mobilization of Hg-OM complexes from catchment areas is the main cause of the transport of $\mathrm{Hg}$ from terrestrial to aquatic ecosystems, as indicated by the similar $\mathrm{Hg}$ and $\mathrm{C}$ concentrations trends at Schurmsee, especially in section III. to section V. (Figure 2A). In addition, the catchment morphometry, e.g., differences in slope gradients and, lake forms, influences the concentration of $\mathrm{Hg}$ in the lake sediments [68]. Furthermore, increases in the $\mathrm{Hg}$ export from catchment soils can be caused by variations in the input of $\mathrm{Hg}$ by atmospheric deposition, e.g., due to increases in industrial activities, and the connectivity between terrestrial and aquatic pools, and decreases in the long-term retention or reemission of $\mathrm{Hg}$ [33]. All these factors can also potentially affect the $\mathrm{Hg}$ accumulation in sediments, even though most of these parameters are similar at both studied sites due to their geographic nearness and similar altitudes. Therefore, a multivariate statistical approach was considered.

\subsection{Environmental Processes Controlling Sediment Geochemistry}

The diverse palynological and chemical compositions of the sediments of Schurmsee and Glaswaldsee are represented by six components (Table 1). The CP1 of the PCA is characterized by large loadings of lithogenic elements $(\mathrm{Zr}, \mathrm{Al}, \mathrm{Mn})$ and contrasting loadings of organic matter $(C, N)$. The source-rock at both lakes is mainly Triassic sandstone, which is usually rich in quartz and partly rich in clay minerals, indicating that the high $\mathrm{Al}$ values in the sediments are geogenic. CP1 may represent a signal of local mineral fluxes due to soil erosion from the relatively steep slopes surrounding the lakes. Increased mineral matter fluxes (e.g., Ti) lead to the dilution of the OM in the sediments, reflected by the contrasting loadings of total carbon. CP2 represents the following signals of human activities in chronological order, starting in the northern Black Forest in the Early Iron Age: grazing $>$ agriculture $>$ mining $[40,53,69]$. With the emergence of the first rural cultures with livestock farming, anthropogenic disturbances and changes in the natural vegetation cover became increasingly common. While the Iron Age deforestation at $2600 \mathrm{yr}$ BP in the region was already high, the Medieval deforestation maximum at $\sim 800 \mathrm{yr}$ BP was two-fold that of the Iron Age and much more extended than modern deforestation [70]. Because there were likely no mining activities in the higher altitude slopes of the two studied lakes, the large loadings of $\mathrm{Pb}(0.91$ and 0.88$)$ suggesting atmospheric deposition as the main process controlling the record of this major pollutant [71]. CP3 represents the decline of an oak-dominated forest followed by the evolution of a mixed forest dominated by fir and 
beech. At Schurmsee, fir was distributed ca. 500 years earlier than beech. This forest change was most likely driven by a change in climatic conditions. According to Rösch [40], there are only weak traces of Neolithic human impacts in the northern Black Forest. Furthermore, there is no evidence for human settlements and land use for at least 2000 years after the occurrence of beech and fir at $\sim 5000 \mathrm{yr}$ BP. CP4 represents the variation of an oak-dominated forest and shows a contrasting Fe loading for Schurmsee. CP5 and CP6 shared variables related to the formation processes of autochthonous versus allochthonous $\mathrm{OM}$ and affiliated trace elements such as $\mathrm{Cu}$ and $\mathrm{Zn}$. Moreover, $\mathrm{Cu}$ is an important co-factor in plastocyanin, a protein essential for the algae photosynthesis and is taken up by algae mainly as $\mathrm{Cu}^{2+}$ [72]. CP5 may have particularly a high importance because changes in aquatic productivity can be responsible for variations of $\mathrm{Hg}$ deposition in the sediments due to increased $\mathrm{Hg}$ scavenging by organic particles and the export of $\mathrm{Hg}$ to the sediment [73-75]. On the other hand, allochthonous organic matter from organic-rich eroded soil from catchments is generally older and more degraded than autochthonous $\mathrm{OM}$ from algae and may lead to higher $\mathrm{Hg}$ fluxes from the catchment to the lake because of the higher Hg:C-ratio $[25,33,63]$.

\subsection{Chronology of Factors Controlling Mercury Accumulation}

While the environmental processes controlling the sediment geochemistry were previously represented by six components for the whole core length, the intensity (i.e., relative importance) of the different processes controlling $\mathrm{Hg}$ accumulation is not steady over time. The cumulative effects of the factors for each lake sediment layer are shown in Figure 4. Based on the classification by vegetation cover type and human impacts, the two sediment records can again be divided into five time periods (section I to section V). In Figure 4, only PCR models 1a and 2a are considered. Regarding the type or environmental meaning of the variables forming the CPs within the PCR, the CPs are labelled follows: CP1 refers to soil erosion and contains opposing elements of minerals and OM. $\mathrm{CP} 2$ combines human impact indicators, e.g., rye for agriculture and $\mathrm{Pb}$ for mining activities. $\mathrm{CP} 3$ is associated with the evolution of mixed mountain forests (i.e., the presence of beech and fir). CP4 is linked to the presence of oak trees. CP5 describes the effect of the C:N ratio, quantifying the influence on $\mathrm{Hg}$ accumulation either from autochthonous or allochthonous OM.

Due to an additional contribution of zinc ( $\mathrm{Zn})$ in CP5 in the PCA at Schurmsee, which resulted in negative loadings for the $\mathrm{C}: \mathrm{N}$ ratio, the bar representation for $\mathrm{CP} 5$ at Schurmsee is opposite of that for $\mathrm{CP} 5$ at Glaswaldsee. CP6 refers to the concentration of $\mathrm{Cu}$, which is only relevant for model 1a. 

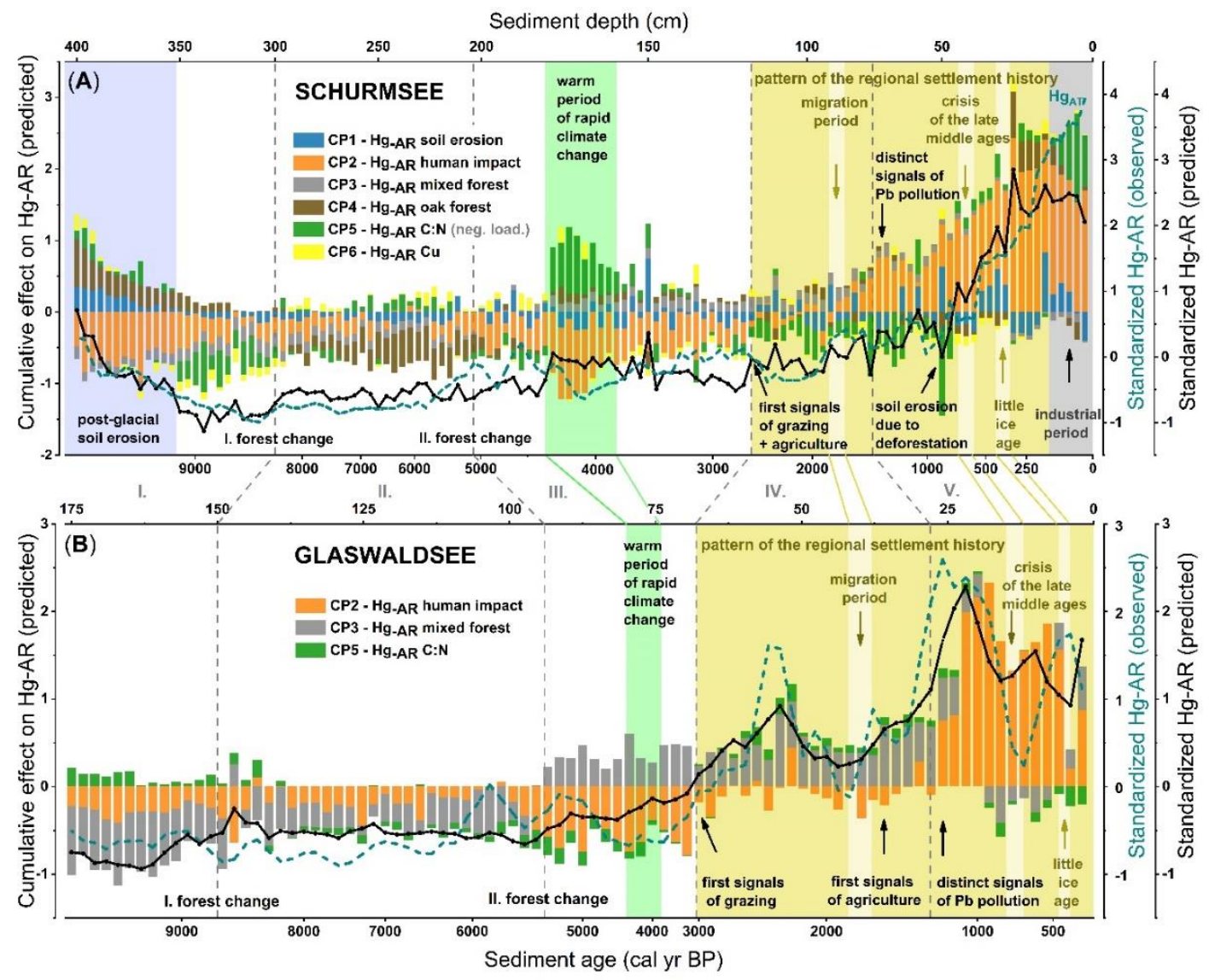

Figure 4. Chronology of the cumulative effects (coloured stacked bars) of the significant factors (CP-Hg-AR) involved in the variations of $\mathrm{Hg}$ accumulation (Hg-AR) at Schurmsee (A) and Glaswaldsee (B) by a lake-specific age-depth distribution. The patterns of climate and local settlement history, records of observed standardized Hg-AR (grey-blue dashed line) and predicted standardized Hg-AR (black line) were obtained by PCR models $1 \mathrm{a}$ and $2 \mathrm{a}$.

\subsubsection{Declining Soil Erosion in an Establishing Hazel-Dominated Shrubland (Section I)}

Intensive soil erosion was observed at Schurmsee until $9200 \mathrm{yr}$ BP and led to higher uncertainties in the age model and unrealistic $\mathrm{Hg}$ accumulation rates (Figure SM-1). After this period of post-glacial soil erosion, the low $\mathrm{Hg}$ accumulation is related to moderate inputs of mineral matter due to a higher erosion of OM under a vegetation cover of mainly hazel. The absences of human influences and mixed forest stands are clearly shown by the negative effects of the CP2 and CP3 factors, respectively. The concentrations of $\mathrm{C}$ are lower under the hazel-dominated forest than under the later oak-dominated forest, which is related to a lower input of OM from hazel stands. Furthermore, the mean C:N ratios between 16.7 and 16.9 indicate the OM was mainly from allochthonous sources in the earliest core section of both lakes [58]. Consistently, the observed and predicted $\mathrm{Hg}$ accumulations show similar courses, even during the post-glacial erosion period.

\subsubsection{Steady Fluxes of Soil Organic Matter in an Oak-Dominated Forest (Section II)}

The predicted $\mathrm{Hg}$ accumulation rates increase moderately after the first forest change from hazel to oak. CP4 reflects the occurrence of an oak-dominated forest in this section. Both sediment cores show a rapid increase in $\mathrm{Hg}$ concentrations (Figure 2) and predicted $\mathrm{Hg}$ accumulation rates at the beginning of this period, although if $\mathrm{CP} 4$ is considered alone, it has a negative effect on $\mathrm{Hg}$ accumulation (Table 2). This result is consistent with the accumulation of a thick organic soil horizon in oak forest stands, which reduces soil erosion, i.e., decreases dilution by mineral matter in the sediment, and increases the flux of DOM-bound Hg to lake sediments [33]. Moreover, compared to the shrubby vegetation 
under hazel, oak trees develop a denser canopy, which could result in an increased interception of atmospheric $\mathrm{Hg}$ and reduce the evasion of volatile $\mathrm{Hg}$ [76-78]. At Schurmsee, the effect of CP4 and CP6 on $\mathrm{Hg}$ accumulation changed from negative to positive, which is likely related to a higher production of autochthonous OM by algae. This transformation can also be seen for CP5 at Glaswaldsee and during 7800-5700 yr BP at Herrenwiesersee [33]. According to a review of natural archives from central Europe by Kalis et al. [79], the Early Atlantic (9000 to 7500 yr BP) was a period characterized by negligible human impacts and relatively stable environmental conditions within the Holocene climatic optimum. Mayer and Schwark [80] have shown, with a stable isotope record obtained from the lacustrine sediment core at Steißlingersee (southwest Germany), an abrupt increase in $\delta^{13} C_{\text {org }}$ during the Early Atlantic, which was explained as a negative water balance signal due to the increased evaporation and temperatures during dry climatic conditions and probably caused the first forest change in the catchments of the studied areas. Eventually, reduced precipitation, decreases in mineral matter fluxes from the catchment and enhanced accumulation of organic matter by litterfall from oak led to higher and more stable $\mathrm{Hg}$ accumulation rates under the oak-dominated forest.

\subsubsection{Warm Period Caused Enhanced Mercury Uptake in Lakes Surrounded by a Mixed Forest} (Section III)

Core section III. represents the final stage of natural forest development in the Holocene, which was triggered by natural processes, namely, only by climate change, soil alteration, plant migration and competition [53]. At the second forest change, i.e., during the transition from an oak-dominated forest to a mountain mixed forest, the lake water balance likely flipped from oligotrophic to dystrophic. This water balance change could have occurred of increased mire formation and acidification in the lake catchments and is indicated by a decline and disappearance of Isoetes (quillworts) [70]. Therefore, the input of dissolved organic carbon (DOC) into the poorly buffered aquatic system increased. Rydberg et al. [33] observed that $\mathrm{Hg}$ concentrations in sediments increased with fir and beech as a result of higher $\mathrm{Hg}: \mathrm{C}$ ratios in the catchment soils, which was also observed in this work (Figure 3). However, because of a decreased input of OM due to the decreased litterfall in mixed forests, there is no indication of increasing $\mathrm{Hg}$ accumulation rates after the second forest change at Herrenwiesersee. In contrast, the predicted $\mathrm{Hg}$ accumulation rates show a slight increase at Schurmsee and a moderate increase at Glaswaldsee up to $4600 \mathrm{yr}$ BP. There is a more pronounced rapid increase in the accumulation of $\mathrm{Hg}$ between $4600-3800 \mathrm{yr} \mathrm{BP}$, which is accompanied by a change towards decreasing $\mathrm{C}: \mathrm{N}$ ratios leading to a positive effect of $\mathrm{CP} 5$ on $\mathrm{Hg}$ accumulation, likely due to the in-lake uptake of $\mathrm{Hg}$ caused by algae. Particularly at lake Schurmsee, the C: N ratios decline rapidly from 15.7 (4542 yr BP) to 12.5 (4490 yr BP). This abrupt change marks a warm period of rapid climate change [81], along with a higher production of autochthonous organic matter by algae and higher $\mathrm{Hg}$ accumulation rates in the sediment.

Furthermore, this core section at Schurmsee is characterized by multiple soil erosion events (Figure 3A) and a sharp decline in $\mathrm{C}$ and $\mathrm{Hg}$ concentrations (Figure 2A), which are particularly pronounced at 4700 and $3500 \mathrm{yr}$ BP. These two events mark climatic transition zones from cold to warm and moderately humid, to again cold climatic conditions, which have been observed via diatom analysis in several sediment cores in northeastern Germany [82-84]. A study from the Swiss alpine lake Meidsee shows erosion events in comparable sediment layers indicated by increasing concentrations of $\mathrm{Ti}$ and $\mathrm{Mn}$ and decreasing concentrations of $\mathrm{Hg}$ and $\mathrm{Pb}$ [35]. Interestingly, the predicted $\mathrm{Hg}$ accumulation at Schurmsee (Figure 4A) decreases until the end of core section III. (3000-2600 yr BP) during colder climatic conditions to values comparable to the mean $\mathrm{Hg}$ accumulation rates of core section II, which was dominated by oak and did not show any significant coniferous tree populations. Moreover, the effect of $\mathrm{CP} 5$ on $\mathrm{Hg}$ accumulation becomes negative (i.e., induced by increased C:N ratios) over the end of this section. This change was caused by increases in the relative importance of terrestrial $\mathrm{OM}$ erosion and leaching from the forest soil to the lake sediments. However, this decline in the predicted $\mathrm{Hg}$ accumulation rate at the end of the Bronze Age is not observed at Glaswaldsee. 


\subsubsection{Distinct Traces of Grazing and Agriculture in a Mixed Forest (Section IV)}

In the Neolithic period, the first farmers began the transformation of the landscape of the Black Forest lowlands into the cultural landscapes of today [85]. At Schurmsee and Glaswaldsee, distinct human impacts can be observed in the Late Bronze Age and Early Roman Iron Age, indicating that grazing started at the same time as cereal cultivation at Schurmsee, while grazing activities near Glaswaldsee developed 2000 years before the first signals of grain cultivation, i.e., pollen of rye. Besides, the presence of ribwort and rye, there is another indicator of human disturbances. The $\mathrm{Pb}$ signal remains relatively low and steady until core section IV. Subsequently, the concentration of $\mathrm{Pb}$ peaks significantly at $\sim 2400 \mathrm{yr}$ BP at Schurmsee and at $\sim 2000 \mathrm{yr}$ BP at Glaswaldsee. For the first time, the $\mathrm{Pb}$ concentration trend follow the $\mathrm{Hg}$ concentration trend (Figure 2). Significant $\mathrm{Pb}$ signals during the period of the Roman Empire are also reported from different lake sediments and peat bogs [35,86-88]. Approximately $2100 \mathrm{yr} \mathrm{BP}$, Roman Pb mining became the most important source of atmospheric $\mathrm{Pb}$ pollution in central Europe [88]. Mariet et al. [86] found, by means of Pb isotopic analyses of the sediments of Lac de Longemer, which is only $109 \mathrm{~km}$ to the northwest from Glaswaldsee on the opposite side of the Rhine Valley, no evidence for early local mining in the Vosges Mountains and linked the observed $\mathrm{Pb}$ isotopic signals at $\sim 2000 \mathrm{yr} \mathrm{BP}$ to Roman origins. However, the first increase in $\mathrm{Pb}$ at Schurmsee started at $2800 \mathrm{yr}$ BP (Figure 2A) and unlike the trends in the aforementioned $\mathrm{Pb}$ studies, the $\mathrm{Pb}$ signal in this sediment core does not drop back to a pre-settlement background value. During an excavation at Neuenbürg, which is only $33 \mathrm{~km}$ away from lake Schurmsee (Figure 1), Grassmann et al. [69] discovered unusually well-preserved smelting complexes for iron and steel. Dated to the Late Hallstatt and Early Latène period (2600-2500 yr BP), these findings provide the earliest proof of iron manufacturing in this region. However, without an extended $\mathrm{Pb}$ isotopic analysis of the two sediment cores, the historical sources of $\mathrm{Pb}$ cannot be disentangled here.

More certain are the increases in $\mathrm{Hg}$ accumulation related to human activities in both sediment cores, while the proportional composition of tree species is relatively steady. The observed proxies for local settlement activities (e.g., rye for agriculture and $\mathrm{Pb}$ for mining activities) increase. Subsequently, the negative effect of the human impacts (CP2) reduced or even changed to a positive influence $\mathrm{Hg}$ accumulation. Compared to the previous warm period in core section III, contrasting effects of CP5 are observed, which may indicate a change in the source of the sedimented OM due to local agricultural activities. Because pollen analysis from eight small headwater lakes in the northern Black Forest showed significant differences in the timing of indicators for grazing and agriculture, we conclude that the lake sediments reflect the vegetation situation of their surroundings, up to a distance of no more than 1-2 km, without any major pollen inputs from greater distances [53]. Furthermore, it is notable that the PCR based prediction of $\mathrm{Hg}$ accumulation decreases at both lakes during a known pattern of regional settlement history, i.e., periods of major demographic crises (Figure 4). The temporary decline in anthropogenic factors during these crises led to lower predicted $\mathrm{Hg}$ accumulations rates. This result is consistent with the observed decline of human activities based on the pollen record (i.e., less agricultural plants), e.g., during the Migration period caused by the decay of the Roman Empire [40].

\subsubsection{Pollution from Mining and Industrial Activities in a Mixed Forest (Section V)}

Mercury and $\mathrm{Pb}$ are emitted to the atmosphere from both anthropogenic and natural sources. However, anthropogenic emissions of these metals have greatly surpassed natural releases to the atmosphere over historical times $[34,89,90]$. With few interruptions, the upper core section documents a continuous increase in human influences in the northern Black Forest. The locations and history of at least six former mining deposits (silver, lead, and zinc) near the lakes are well described (Figure 1). The mining activity, e.g., near the town of Freudenstadt, is noted for the first time in 1267 [91,92]. The local ore mining affected the chemical composition of the lake sediment cores noticeably. At Glaswaldsee, the $\mathrm{Pb}$ maximum was more than three-fold higher than at Schurmsee, which is likely related to the near Wildschapach historical mining site. A striking feature is also the rapid and simultaneous increases in the $\mathrm{Hg}$ and $\mathrm{Pb}$ concentrations at Glaswaldsee after the charcoal 
maximum at $\sim 1100 \mathrm{yr} B P$, which are followed by a strong event of soil erosion due to deforestation caused by local mining (Figure 2B). Breitenlechner et al. [93] found increasing values of charcoal in a peat deposit affiliated with a boom of silver mining 1500 in western Austria. An increase in the $\mathrm{Hg}$ export from the lake catchments to the sediments during Medieval mining activities can be caused (i) by $\mathrm{Hg}$ release as a mining by-product of the excavated zinc-rich ores [94], (ii) due to the use of $\mathrm{Hg}$ in silver mining to amalgamate and concentrate the precious metal $[95,96]$, (iii) by the release of bound $\mathrm{Hg}$ from the topsoil and burning of biomass after forest clearances [97-99] or through the local production of charcoal for mining $[93,100]$.

Up to the High Medieval period, the predicted and observed $\mathrm{Hg}$ accumulation rates increase rapidly (Figure 4). Moreover, the effect of human influences (CP2) on $\mathrm{Hg}$ accumulation becomes positive in the last core section. Declines in the predicted $\mathrm{Hg}$ accumulation occurred during the crises of the Late Middle Ages, such as famines and plagues, especially the Black Death epidemic of 1347 to 1353 [101,102], and during the Little Ice Age, when unfavourable climatic conditions were followed by transnational political conflicts that significantly decimated the population in central Europe [103,104].

Furthermore, another development in human history is crucial for the accumulation of $\mathrm{Hg}$ in lake sediments. Overall, the industrial revolution beginning in the 1850s in Germany was characterized by investments in railway construction and heavy industry [105]. Exemplary, in 1846 only 1518 steam engines were registered in the territory of the German Customs Union. This number had already increased to 8695 by 1861 [106]. During this short period, coal as a primary energy source increased from $25 \%$ to $47 \%$ of the total nationwide energy consumption and peaked at $93 \%$ in $1942[107,108]$. This rapid increase in coal combustion and the related additional release of $\mathrm{Hg}$ to the atmosphere $[109,110]$ are reflected by an increase in the $\mathrm{Hg}$ concentration (Figure 2A) and observed $\mathrm{Hg}$ accumulation rates (Figure 3A) in the sediment core of Schurmsee. Here, only the Schurmsee core contains signals of geochemical transitions during the industrial period. This observation raises the question why this additional atmospheric $\mathrm{Hg}\left(\mathrm{Hg}_{\mathrm{AT}}\right)$ input is not observed in the predicted $\mathrm{Hg}$ accumulation rates. The reason for this aberration may be a missing proxy for the additional input of $\mathrm{Hg}$ due to the combustion of fossil fuels after the beginning of the industrial revolution began. As mentioned above, the $\mathrm{Hg}$ concentration was not entered as a variable in the model. Thus, the PCR led to an underestimated value for the predicted $\mathrm{Hg}$ accumulation in the top five sediment layers $(0-10 \mathrm{~cm})$, which reflect the past 140-150 years of industrial activities.

\section{Conclusions}

Our results indicate that the deposition of $\mathrm{Hg}$ in the sediments of two lakes in the Black Forest prior to $\sim 3000 \mathrm{yr} \mathrm{BP}$ was caused by natural processes only, mainly by the quantity and composition of the forest vegetation. Consistent with our hypothesis, the establishment of conifers in the catchments validated the higher $\mathrm{Hg}$ concentrations in the lake sediments. However, there was no evidence for a substantial increase in $\mathrm{Hg}$ accumulation rates caused by the dominance of conifers. More than $\sim 2000 \mathrm{yr}$ after a mixed mountain forest was established, anthropogenic factors such as increased soil erosion after deforestation, grazing, agriculture activities, and emissions from mining and industry triggered changes in $\mathrm{Hg}$ accumulation stronger than natural changes in the forest composition alone. Our study demonstrates that a valid prediction of $\mathrm{Hg}$ accumulation rates can be obtained by a multiproxy stepwise regression analysis of lake sediment cores with well-defined pollen and geochemical records. Furthermore, this statistical approach offers to define and quantify controlling factors on $\mathrm{Hg}$ accumulation in forested areas over time.

Supplementary Materials: The following are available online at http:/ /www.mdpi.com/2076-3263/8/10/358/s1, Figure SM-1: Age-depth model of Schurmsee, developed using CLAM 2.2. They grey shaded area represents the confidence interval of the model. The age calendar age distribution of each sample included in the model is marked in green, Figure SM-2: Age-depth model of Glaswaldsee, developed using CLAM 2.2. The grey shaded area represents the confidence interval of the model. The age calendar age distribution of each sample included in the model is marked in blue, while one sample that was excluded from the model is marked in red, Table SM-1: Carbon-14 dates for 17 dated bulk sediment samples from Schurmsee, including uncertainties and $\delta 13 \mathrm{C}$ values, 
SM-2: Carbon-14 dates for 16 dated bulk sediment samples from Glaswaldsee, including uncertainties and $813 \mathrm{C}$ values. The values in parenthesis indicate one sample which was removed from the age-depth model.

Author Contributions: M.S. performed the chemical analyses, the interpretation of the results, the graphical presentation and wrote the paper. G.T. investigated the palynological record of Schurmsee. M.P.-R. assisted with the statistical analyses and interpretation. M.R. conceived of the sediment core sampling project in the Black Forest and investigated the palynological record of Glaswaldsee. H.B. conceived of the funding acquisition and led this research project.

Funding: This research was supported by the German Science Foundation (DFG Research Grants: BI 734/15-1 and RO 2282/4).

Acknowledgments: We thank P. Schmidt, A. Calean, A. Alten, M. Grobe, J. Haller-Jans (TU Braunschweig) and E. Klimek, R. Schneider, T. Märkle (Landesamt für Denkmalpflege) for the help with sample preparation and laboratory analyses.

Conflicts of Interest: The authors declare no conflicts of interest.

\section{References}

1. Sheehan, K.D.; Fernandez, I.J.; Kahl, J.S.; Amirbahman, A. Litterfall Mercury in Two Forested Watersheds at Acadia National Park, Maine, USA. Water Air Soil Pollut. 2006, 170, 249-265. [CrossRef]

2. Xia, K.; Skyllberg, U.L.; Bleam, W.F.; Bloom, P.R.; Nater, E.A.; Helmke, P.A. X-ray absorption spectroscopic evidence for the complexation of HG(II) by reduced sulfur in soil humic substances. Sci. Technol. 1999, 33, 257-261. [CrossRef]

3. Biester, H.; Bindler, R.; Martinez Cortizas, A.; Engstrom, D.R. Modeling the past atmospheric deposition of mercury using natural archives. Environ. Sci. Technol. 2007, 41, 4851-4860. [CrossRef] [PubMed]

4. Swain, E.B.; Engstrom, D.R.; Brigham, M.E.; Henning, T.A.; Brezonik, P.L. Increasing Rates of Atmospheric Mercury Deposition in Midcontinental North America. Science 1992, 257, 784-787. [CrossRef] [PubMed]

5. Yang, H.; Engstrom, D.R.; Rose, N.L. Recent changes in atmospheric mercury deposition recorded in the sediments of remote equatorial lakes in the Rwenzori Mountains, Uganda. Environ. Sci. Technol. 2010, 44, 6570-6575. [CrossRef] [PubMed]

6. Rydberg, J.; Klaminder, J.; Rosén, P.; Bindler, R. Climate driven release of carbon and mercury from permafrost mires increases mercury loading to sub-arctic lakes. Sci. Total Environ. 2010, 408, 4778-4783. [CrossRef] [PubMed]

7. Ravichandran, M. Interactions between mercury and dissolved organic matter-A review. Chemosphere 2004, 55, 319-331. [CrossRef] [PubMed]

8. Hart, B.T. Uptake of trace metals by sediments and suspended particulates: A review. In Sediment/Freshwater Interaction; Springer: Dordrecht, The Netherlands, 1982; pp. 299-313.

9. Brännvall, M.-L.; Bindler, R.; Emteryd, O.; Nilsson, M.; Renberg, I. Stable isotope and concentration records of atmospheric lead pollution in peat and lake sediments in Sweden. Water Air Soil Pollut. 1997, 100, $243-252$. [CrossRef]

10. Engstrom, D.R. Lake Development in the Boreal Peatlands of Southeastern Labrador, Canada. Arct. Alp. Res. 1984, 16, 447-452. [CrossRef]

11. Hermanns, Y.M.; Biester, H. A 17,300-year record of mercury accumulation in a pristine lake in southern Chile. J. Paleolimnol. 2013, 49, 547-561. [CrossRef]

12. Guevara, S.R.; Meili, M.; Rizzo, A.; Daga, R.; Arribere, M. Sediment records of highly variable mercury inputs to mountain lakes in Patagonia during the past millennium. Atmos. Chem. Phys. 2010, 10, 3443-3453. [CrossRef]

13. Bindler, R.; Olofsson, C.; Renberg, I.; Frech, W. Temporal Trends in Mercury Accumulation in Lake Sediments in Sweden. Water Air Soil Pollut. 2001, 1, 343-355. [CrossRef]

14. Koinig, K.A.; Shotyk, W.; Lotter, A.F.; Ohlendorf, C.; Sturm, M. 9000 years of geochemical evolution of lithogenic major and trace elements in the sediment of an alpine lake-The role of climate, vegetation, and land-use history. J. Paleolimnol. 2003, 30, 307-320. [CrossRef]

15. Armstrong, A.; Holden, J.; Luxton, K.; Quinton, J.N. Multi-scale relationship between peatland vegetation type and dissolved organic carbon concentration. Ecol. Eng. 2012, 47, 182-188. [CrossRef] 
16. Smolander, A.; Loponen, J.; Suominen, K.; Kitunen, V. Organic matter characteristics and C and N transformations in the humus layer under two tree species, Betula pendula and Picea abies. Soil Biol. Biochem. 2005, 37, 1309-1318. [CrossRef]

17. Hansson, K.; Olsson, B.A.; Olsson, M.; Johansson, U.; Kleja, D.B. Differences in soil properties in adjacent stands of Scots pine, Norway spruce and silver birch in SW Sweden. For. Ecol. Manag. 2011, 262, 522-530. [CrossRef]

18. Berg, B. Litter decomposition and organic matter turnover in northern forest soils. For. Ecol. Manag. 2000, 133, 13-22. [CrossRef]

19. Koorem, K.; Moora, M. Positive association between understory species richness and a dominant shrub species (Corylus avellana) in a boreonemoral spruce forest. For. Ecol. Manag. 2010, 260, 1407-1413. [CrossRef]

20. Van Nevel, L.; Mertens, J.; De Schrijver, A.; Baeten, L.; De Neve, S.; Tack, F.M.G.; Meers, E.; Verheyen, K. Forest floor leachate fluxes under six different tree species on a metal contaminated site. Sci. Total Environ. 2013, 447, 99-107. [CrossRef] [PubMed]

21. Obrist, D.; Johnson, D.W.; Edmonds, R.L. Effects of vegetation type on mercury concentrations and pools in two adjacent coniferous and deciduous forests. J. Plant Nutr. Soil Sci. 2012, 175, 68-77. [CrossRef]

22. Schwesig, D.; Matzner, E. Pools and fluxes of mercury and methylmercury in two forested catchments in Germany. Sci. Total Environ. 2000, 260, 213-223. [CrossRef]

23. Demers, J.D.; Driscoll, C.T.; Fahey, T.J.; Yavitt, J.B. Mercury cycling in litter and soil in different forest types in the Adirondack region, New York, USA. Ecol. Appl. 2007, 17, 1341-1351. [CrossRef] [PubMed]

24. Navrátil, T.; Shanley, J.B.; Rohovec, J.; Oulehle, F.; Šimeček, M.; Houška, J.; Cudlín, P. Soil mercury distribution in adjacent coniferous and deciduous stands highly impacted by acid rain in the Ore Mountains, Czech Republic. Appl. Geochem. 2016, 75, 63-75. [CrossRef]

25. Jiskra, M.; Wiederhold, J.G.; Skyllberg, U.; Kronberg, R.-M.; Hajdas, I.; Kretzschmar, R. Mercury Deposition and Re-emission Pathways in Boreal Forest Soils Investigated with $\mathrm{Hg}$ Isotope Signatures. Environ. Sci. Technol. 2015, 49, 7188-7196. [CrossRef] [PubMed]

26. Navrátil, T.; Shanley, J.; Rohovec, J.; Hojdová, M.; Penížek, V.; Buchtová, J. Distribution and Pools of Mercury in Czech Forest Soils. Water Air Soil Pollut. 2014, 225, 1829. [CrossRef]

27. Drenner, R.W.; Chumchal, M.M.; Jones, C.M.; Lehmann, C.M.B.; Gay, D.A.; Donato, D.I. Effects of Mercury Deposition and Coniferous Forests on the Mercury Contamination of Fish in the South Central United States. Environ. Sci. Technol. 2013, 47, 1274-1279. [CrossRef] [PubMed]

28. Hare, A.A.; Stern, G.A.; Kuzyk, Z.Z.A.; MacDonald, R.W.; Johannessen, S.C.; Wang, F. Natural and anthropogenic mercury distribution in marine sediments from Hudson Bay, Canada. Environ. Sci. Technol. 2010, 44, 5805-5811. [CrossRef] [PubMed]

29. Renberg, I.; Persson, M.W.; Emteryd, O. Pre-industrial atmospheric lead contamination detected in Swedish lake sediments. Nature 1994, 368, 323-326. [CrossRef]

30. Rose, N.; Yang, H.; Turner, S.D.; Simpson, G. An assessment of the mechanisms for the transfer of lead and mercury from atmospherically contaminated organic soils to lake sediments with particular reference to Scotland, UK. Geochim. Cosmochim. Acta 2012, 82, 113-135. [CrossRef]

31. Rydberg, J.; Karlsson, J.; Nyman, R.; Wanhatalo, I.; Näthe, K.; Bindler, R. Importance of vegetation type for mercury sequestration in the northern Swedish mire, Rödmossamyran. Geochim. Cosmochim. Acta 2010, 74, 7116-7126. [CrossRef]

32. Pompeani, D.P.; Cooke, C.A.; Abbott, M.B.; Drevnick, P.E. Climate, Fire, and Vegetation Mediate Mercury Delivery to Midlatitude Lakes over the Holocene. Environ. Sci. Technol. 2018, 52, 8157-8164. [CrossRef] [PubMed]

33. Rydberg, J.; Rösch, M.; Heinz, E.; Biester, H. Influence of catchment vegetation on mercury accumulation in lake sediments from a long-term perspective. Sci. Total Environ. 2015, 538, 896-904. [CrossRef] [PubMed]

34. Martínez-Cortizas, A.; Pontevedra-Pombal, X.; García-Rodeja, E.; Nóvoa-Muñoz, J.C.; Shotyk, W. Mercury in a spanish peat bog: Archive of climate change and atmospheric metal deposition. Science 1999, 284, 939-942. [CrossRef] [PubMed]

35. Thevenon, F.; Guédron, S.; Chiaradia, M.; Loizeau, J.-L.; Poté, J. (Pre-)historic changes in natural and anthropogenic heavy metals deposition inferred from two contrasting Swiss Alpine lakes. Quat. Sci. Rev. 2011, 30, 224-233. [CrossRef] 
36. Geological Survey of Baden-Württemberg LGRB-Kartenviewer. Available online: http:/ / maps.lgrb-bw.de/ (accessed on 6 March 2018).

37. German Meteorological Service Wetter und Klima-Deutscher Wetterdienst-Fachinformationsdienst Meteorologie. Available online: https://www.dwd.de/DE/derdwd/bibliothek/fachinfodienst/ recherchetipps.htm (accessed on 5 March 2018).

38. Hinderer, M.; Jüttner, I.; Winkler, R.; Steinberg, C.E.; Kettrup, A. Comparing trends in lake acidification using hydrochemical modelling and paleolimnology: The case of the Herrenwieser See, Black Forest, Germany. Sci. Total Environ. 1998, 218, 113-121. [CrossRef]

39. Berglund, B.E.; Birks, H.J.B.; Ralska-Jasiewiczowa, M.; Wright, H.E. Palaeoecological Events During the Last 15,000 Years: Regional Synthesis of Palaeoecological Studies of Lakes and Mires in Europe; John Wiley \& Sons: Chichester, UK, 1996.

40. Rösch, M. Botanical evidence for prehistoric and medieval land use in Black Forest. Medieval Rural Settlement in Marginal Landscapes. Ruralia 2007, VII, 335-343.

41. Livingstone, D.A. A Lightweight Piston Sampler for Lake Deposits. Ecology 1955, 36, 137-139. [CrossRef]

42. Rösch, M. Nationalpark-Natur-Weißtanne-Fichte. Sechs Jahrtausende Wald und Mensch im Nordschwarzwald. Denkmalpfl. Baden-Württ. Landesdenkmalpflege 2015, 44, 154-159.

43. Rösch, M.; Lechterbeck, J. Seven Millennia of human impact as reflected in a high resolution pollen profile from the profundal sediments of Litzelsee, Lake Constance region, Germany. Veg. Hist. Archaeobotany 2016, 25, 339-358. [CrossRef]

44. Reimer, P.J.; Bard, E.; Bayliss, A.; Beck, J.W.; Blackwell, P.G.; Ramsey, C.B.; Buck, C.E.; Cheng, H.; Edwards, R.L.; van der Plicht, J.; et al. IntCal13 and Marine13 Radiocarbon Age Calibration Curves 0-50,000 Years cal BP. Radiocarbon 2013, 55, 1869-1887. [CrossRef]

45. Blaauw, M. Methods and code for classical age-modelling of radiocarbon sequences. Quat. Geochronol. 2010, 5, 512-518. [CrossRef]

46. Meyers, P.A.; Ishiwatari, R. Lacustrine organic geochemistry-An overview of indicators of organic matter sources and diagenesis in lake sediments. Org. Geochem. 1993, 20, 867-900. [CrossRef]

47. Müller, G.; Gastner, M. The Karbonat-Bombe, a simple device for the determination of carbonate content in sediments, soils and other materials. Neues Jahrbuch für Mineralogie-Monatshefte 1971, 10, 466-469.

48. Cheburkin, A.K.; Shotyk, W. An energy-dispersive miniprobe multielement analyzer (EMMA) for direct analysis of $\mathrm{Pb}$ and other trace elements in peats. Fresenius J. Anal. Chem. 1996, 354, 688-691. [CrossRef] [PubMed]

49. US EPA. US EPA Method 7473 US EPA Method 7473 (SW-846): Mercury in Solids and Solutions by Thermal Decomposition, Amalgamation, and Atomic Absorption Spectrophotometry; US EPA: Washington, DC, USA, 1998.

50. Eriksson, L.; Johansson, E.; Kettaneh-Wold, N.W.S. Introduction to Multi and Megavariate Data Analysis Using Projection Methods (PCS \& PLS); Umetrics: San Jose, CA, USA, 1999.

51. Pérez-Rodríguez, M.; Horák-Terra, I.; Rodríguez-Lado, L.; Aboal, J.R.; Martínez Cortizas, A. Long-Term ( $\sim 57 \mathrm{ka}$ ) Controls on Mercury Accumulation in the Souther Hemisphere Reconstructed Using a Peat Record from Pinheiro Mire (Minas Gerais, Brazil). Environ. Sci. Technol. 2015, 49, 1356-1364. [CrossRef] [PubMed]

52. R Core Team. R: A Language and Environment for Statistical Computing; R Foundation: Vienna, Austria, 2016.

53. Rösch, M. Abies alba and Homo sapiens in the Schwarzwald-A Difficult Story. Interdiscip. Archaeol. 2015, 6, 47-62. [CrossRef]

54. Munthe, J.; Hultberg, H.; Lee, Y.-H.; Parkman, H.; Iverfeldt, A.; Renberg, I. Trends of mercury and methylmercury in deposition, run-off water and sediments in relation to experimental manipulations and acidification. Water Air Soil Pollut. 1995, 85, 743-748. [CrossRef]

55. Yang, H.; Rose, N.L. Distribution of mercury in six lake sediment cores across the UK. Sci. Total Environ. 2003, 304, 391-404. [CrossRef]

56. Corella, J.P.; Saiz-Lopez, A.; Sierra, M.J.; Mata, M.P.; Millán, R.; Morellón, M.; Cuevas, C.A.; Moreno, A.; Valero-Garcés, B.L. Trace metal enrichment during the Industrial Period recorded across an altitudinal transect in the Southern Central Pyrenees. Sci. Total Environ. 2018, 645, 761-772. [CrossRef] [PubMed]

57. Cannon, W.F.; Dean, W.E.; Bullock, J.H. Effects of Holocene climate change on mercury deposition in Elk Lake, Minnesota: The importance of eolian transport in the mercury cycle. Geology 2003, 31, 187-190. [CrossRef] 
58. Hermanns, Y.M.; Biester, H. Anthropogenic mercury signals in lake sediments from southernmost Patagonia, Chile. Sci. Total Environ. 2013, 445-446, 126-135. [CrossRef] [PubMed]

59. Vandal, G.M.; Fitzgerald, W.F.; Boutron, C.F.; Candelone, J.-P. Variations in mercury deposition to Antarctica over the past 34,000 years. Nature 1993, 362, 621-623. [CrossRef]

60. Fitzgerald, W.F.; Engstrom, D.R.; Lamborg, C.H.; Tseng, C.-M.; Balcom, P.H.; Hammerschmidt, C.R. Modern and Historic Atmospheric Mercury Fluxes in Northern Alaska: Global Sources and Arctic Depletion. Environ. Sci. Technol. 2005, 39, 557-568. [CrossRef] [PubMed]

61. Driscoll, C.T.; Blette, V.; Yan, C.; Schofield, C.L.; Munson, R.; Holsapple, J. The role of dissolved organic carbon in the chemistry and bioavailability of mercury in remote Adirondack lakes. Water Air Soil Pollut. 1995, 80, 499-508. [CrossRef]

62. Kolka, R.K.; Nater, E.A.; Grigal, D.F.; Verry, E.S. Atmospheric Inputs of Mercury and Organic Carbon into a Forested Upland/Bog Watershed. Water Air. Soil Pollut. 1999, 113, 273-294. [CrossRef]

63. Ouellet, J.-F.; Lucotte, M.; Teisserenc, R.; Paquet, S.; Canuel, R. Lignin biomarker as tracers of mercury in lakes water column. Biogeochemistry 2009, 94, 123-140. [CrossRef]

64. Teisserenc, R.; Lucotte, M.; Houel, S.; Carreau, J. Integrated transfers of terrigenous organic matter to lakes at their watershed level: A combined biomarker and GIS analysis. Geochim. Cosmochim. Acta 2010, 74, 6375-6386. [CrossRef]

65. Rydberg, J.; Rosén, P.; Lambertsson, L.; De Vleeschouwer, F.; Tomasdotter, S.; Bindler, R. Assessment of the spatial distributions of total- and methyl-mercury and their relationship to sediment geochemistry from a whole-lake perspective. J. Geophys. Res. Biogeosci. 2012, 117, 1-13. [CrossRef]

66. Blais, J.M.; Kalff, J.; Cornett, R.J.; Evans, R.D. Evaluation of U210Pb dating in lake sediments using stable Pb, Ambrosia pollen, and 137Cs. J. Paleolimnol. 1995, 13, 169-178.

67. MSC-E. Data of HMs and POPs for the EMEP Region; Meteorological Synthesizing Centre-East: Moscow, Russian, 2017.

68. Kainz, M.; Lucotte, M. Mercury Concentrations in Lake Sediments-Revisiting the Predictive Power of Catchment Morphometry and Organic Matter Composition. Water Air Soil Pollut. 2006, 170, 173-189. [CrossRef]

69. Grassmann, G.; Wieland, G.; Rösch, M. Das Neuenbürger Erzevier im Nordschwarzwald als Wirtschaftsraum während der Späthallstatt- und dem Frühlatènezeit. Ger. Anz. Röm.-Ger. Kom. Dtsch. Archäol. Inst. 2006, 84, 273-306.

70. Rösch, M.; Tserendorj, G. Florengeschichtliche Beobachtungen im Nordschwarzwald (Südwestdeutschland). Hercynia-Ökol. Umw. Mitteleur. 2011, 44, 53-71.

71. Corella, J.P.; Valero-Garcés, B.L.; Wang, F.; Martínez-Cortizas, A.; Cuevas, C.A.; Saiz-Lopez, A. 700 years reconstruction of mercury and lead atmospheric deposition in the Pyrenees (NE Spain). Atmos. Environ. 2017, 155, 97-107. [CrossRef]

72. Brooks, M.L.; Meyer, J.S.; McKnight, D.M. Photooxidation of wetland and riverine dissolved organic matter: altered copper complexation and organic composition. Hydrobiologia 2007, 579, 95-113. [CrossRef]

73. Biester, H.; Pérez-Rodríguez, M.; Gilfedder, B.-S.; Martínez Cortizas, A.; Hermanns, Y.-M. Solar irradiance and primary productivity controlled mercury accumulation in sediments of a remote lake in the Southern Hemisphere during the past 4000 years: Primary productivity and mercury accumulation. Limnol. Oceanogr. 2018, 63, 540-549. [CrossRef]

74. Outridge, P.M.; Sanei, H.; Stern, G.A.; Hamilton, P.B.; Goodarzi, F. Evidence for control of mercury accumulation rates in Canadian High Arctic Lake sediments by variations of aquatic primary productivity. Environ. Sci. Technol. 2007, 41, 5259-5265. [CrossRef] [PubMed]

75. Pérez-Rodríguez, M.; Gilfedder, B.-S.; Hermanns, Y.-M.; Biester, H. Solar Output Controls Periodicity in Lake Productivity and Wetness at Southernmost South America. Sci. Rep. 2016, 6, 1-7. [CrossRef] [PubMed]

76. Gustin, M.S.; Engle, M.; Ericksen, J.; Lyman, S.; Stamenkovic, J.; Xin, M. Mercury exchange between the atmosphere and low mercury containing substrates. Appl. Geochem. 2006, 21, 1913-1923. [CrossRef]

77. Lindberg, S.E. Forests and the global biogeochemical cycle of mercury: the importance of understanding air/vegetation exchange processes. In Global and Regional Mercury Cycles: Sources, Fluxes and Mass Balances; Springer: Dordrecht, The Netherlands, 1996; pp. 359-380.

78. Witt, E.L.; Kolka, R.K.; Nater, E.A.; Wickman, T.R. Influence of the Forest Canopy on Total and Methyl Mercury Deposition in the Boreal Forest. Water Air Soil Pollut. 2009, 199, 3-11. [CrossRef] 
79. Kalis, A.J.; Merkt, J.; Wunderlich, J. Environmental changes during the Holocene climatic optimum in central Europe-human impact and natural causes. Quat. Sci. Rev. 2003, 22, 33-79. [CrossRef]

80. Mayer, B.; Schwark, L. A 15,000-year stable isotope record from sediments of Lake Steisslingen, Southwest Germany. Chem. Geol. 1999, 161, 315-337. [CrossRef]

81. Mayewski, P.A.; Rohling, E.E.; Stager, J.C.; Karlén, W.; Maasch, K.A.; Meeker, L.D.; Meyerson, E.A.; Gasse, F.; van Kreveld, S.; Steig, E.J.; et al. Holocene climate variability. Quat. Res. 2004, 62, 243-255. [CrossRef]

82. Schönfelder, I.; Giesecke, T.H.; Gelbrecht, J.; Steinberg, C. Paleolimnological investigations on Late Glacial and Holocene sediments of lake Großer Treppelsee (Brandenburg). Berichte IGB 2000, 10, 171-184.

83. Schönfelder, I.; Steinberg, C. Paläolimnologische Analyse Fluviatiler Sedimente der Spree; Final Report for DFG: Berlin, Germany, 1998.

84. Schönfelder, I.; Steinberg, C.E.W. How did the nutrient concentrations change in northeastern german lowland rivers during the last four millennia?-A paleolimnological study of floodplain sediments. Stud. Quat. 2004, 129-138.

85. Rösch, M. Land use and food production in central Europe from the Neolithic to the Medieval period: change of landscape, soils and agricultural systems according to archaeobotanical data. Econ. Archaeol. Struct. Perform. Eur. Archaeol. 2013, 109-127.

86. Mariet, A.-L.; Monna, F.; Gimbert, F.; Walter-Simonnet, A.-V. Tracking past mining activity using trace metals, lead isotopes and compositional data analysis of a sediment core from Longemer Lake, Vosges Mountains, France. J. Paleolimnol. 2018, 60, 399-412. [CrossRef]

87. Martín-Puertas, C.; Jiménez-Espejo, F.; Martínez-Ruiz, F.; Nieto-Moreno, V.; Rodrigo, M.; Mata, M.P.; Valero-Garcés, B.L. Late Holocene climate variability in the southwestern Mediterranean region: An integrated marine and terrestrial geochemical approach. Clim. Past 2010, 6, 807-816. [CrossRef]

88. Shotyk, W.; Weiss, D.; Appleby, P.G.; Cheburkin, A.K.; Frei, R.; Gloor, M.; Kramers, J.D.; Reese, S.; Van Der Knaap, W.O. History of Atmospheric Lead Deposition Since 12,370 14C yr BP from a Peat Bog, jura Mountains, Switzerland; American Association of the of the Advancement of Sciences: Washington, DC, USA, 1998; pp. 1635-1640.

89. Amos, H.M.; Sonke, J.E.; Obrist, D.; Robins, N.; Hagan, N.; Horowitz, H.M.; Mason, R.P.; Witt, M.; Hedgecock, I.M.; Corbitt, E.S.; et al. Observational and Modeling Constraints on Global Anthropogenic Enrichment of Mercury. Environ. Sci. Technol. 2015, 49, 4036-4047. [CrossRef] [PubMed]

90. Engstrom, D.R.; Fitzgerald, W.F.; Cooke, C.A.; Lamborg, C.H.; Drevnick, P.E.; Swain, E.B.; Balogh, S.J.; Balcom, P.H. Atmospheric Hg Emissions from Preindustrial Gold and Silver Extraction in the Americas: A Reevaluation from Lake-Sediment Archives. Environ. Sci. Technol. 2014, 48, 6533-6543. [CrossRef] [PubMed]

91. Bliedtner, M.; Martin, M. Erz-und Minerallagerstätten des Mittleren Schwarzwald; LRGB: Freiburg, Germany, 1986.

92. Metz, R.; Richter, M.; Schürenberg, H. Die Blei-Zink-Erzgänge des Schwarzwaldes; Beihefte zum Geologischen Jahrbuch; Amt für Bodenforschung: Hannover, Germany, 1957.

93. Breitenlechner, E.; Hilber, M.; Lutz, J.; Kathrein, Y.; Unterkircher, A.; Oeggl, K. The impact of mining activities on the environment reflected by pollen, charcoal and geochemical analyses. J. Archaeol. Sci. 2010, 37, 1458-1467. [CrossRef]

94. Schwartz, M.O. Mercury in Zinc Deposits: Economic Geology of a Polluting Element. Int. Geol. Rev. 1997, 39, 905-923. [CrossRef]

95. Lacerda, L.D. Global mercury emissions from gold and silver mining. Water Air Soil Pollut. 1997, 97, $209-221$. [CrossRef]

96. Rytuba, J.J. Mercury from mineral deposits and potential environmental impact. Environ. Geol. 2003, 326-338. [CrossRef]

97. Brunke, E.-G.; Labuschagne, C.; Slemr, F. Gaseous mercury emissions from a fire in the Cape Peninsula, South Africa, during January 2000. Geophys. Res. Lett. 2001, 28, 1483-1486. [CrossRef]

98. Friedli, H.R.; Radke, L.F.; Lu, J.Y. Mercury in smoke from biomass fires. Geophys. Res. Lett. 2001, 28, 3223-3226. [CrossRef]

99. Nelson, S.J.; Johnson, K.B.; Kahl, J.S.; Haines, T.A.; Fernandez, I.J. Mass Balances of Mercury and Nitrogen in Burned and Unburned Forested Watersheds at Acadia National Park, Maine, USA. Environ. Monit. Assess. 2007, 126, 69-80. [CrossRef] [PubMed] 
100. Ko, D.W.; Sparrow, A.D.; Weisberg, P.J. Land-use legacy of historical tree harvesting for charcoal production in a semi-arid woodland. For. Ecol. Manag. 2011, 261, 1283-1292. [CrossRef]

101. Buntgen, U.; Tegel, W.; Nicolussi, K.; McCormick, M.; Frank, D.; Trouet, V.; Kaplan, J.O.; Herzig, F.; Heussner, K.-U.; Wanner, H.; et al. 2500 Years of European Climate Variability and Human Susceptibility. Science 2011, 331, 578-582. [CrossRef] [PubMed]

102. Schmid, B.V.; Büntgen, U.; Easterday, W.R.; Ginzler, C.; Walløe, L.; Bramanti, B.; Stenseth, N.C. Climate-driven introduction of the Black Death and successive plague reintroductions into Europe. Proc. Natl. Acad. Sci. USA 2015, 112, 3020-3025. [CrossRef] [PubMed]

103. Rabb, T.K. The Effects of the Thirty Years' War on the German Economy. J. Mod. Hist. 1962, 34, 40-51. [CrossRef]

104. Rumsby, B.T.; Macklin, M. River response to the last neoglacial (the 'Little Ice Age') in northern, western and central Europe. Geol. Soc. Lond. Spec. Publ. 1996, 115, 217-233. [CrossRef]

105. Pierenkemper, T. Wirtschaftsgeschichte: Eine Einführung-Oder: Wie wir Reich Wurden; Oldenbourg: Leipzig, Germany, 2005.

106. Fremdling, R. Modernisierung und Wachstum der Schwerindustrie in Deutschland, 1830-1860. Gesch. Ges. 1979, 5, 201-227.

107. Joint Center for History and Economics Long-Term Energy Transitions, Germany. Available online: https: / / ourworldindata.org/ energy-production-and-changing-energy-sources (accessed on 11 June 2018).

108. Kander, A.; Malanima, P.; Warde, P. Power to the People: Energy in Europe over the Last Five Centuries; Princeton University Press: Princeton, NJ, USA, 2014.

109. Fitzgerald, W.F.; Engstrom, D.R.; Hammerschmidt, C.R.; Lamborg, C.H.; Balcom, P.H.; Lima-Braun, A.L.; Bothner, M.H.; Reddy, C.M. Global and Local Sources of Mercury Deposition in Coastal New England Reconstructed from a Multiproxy, High-Resolution, Estuarine Sediment Record. Environ. Sci. Technol. 2018, 52, 7614-7620. [CrossRef] [PubMed]

110. Pirrone, N.; Keeler, G.J.; Nriagu, J.O. Regional differences in worldwide emissions of mercury to the atmosphere. Atmos. Environ. 1996, 30, 2981-2987. [CrossRef]

(C) 2018 by the authors. Licensee MDPI, Basel, Switzerland. This article is an open access article distributed under the terms and conditions of the Creative Commons Attribution (CC BY) license (http:/ / creativecommons.org/licenses/by/4.0/). 